\title{
Savaş Ekonomisi ve Varlık Vergisi Üzerine Bir Değerlendirme
}

\author{
Sabit DOKUYAN*
}

Savaş Ekonomisi ve Varlık Vergisi Üzerine Bir
Değerlendirme

Özet

Türkiye İkinci Dünya Savaşı́na katılmamasına rağmen, savaşın ekonomik yansımalarını çok ciddi şekilde yaşamıştır. Yeni gelir kapıları arayan CHP iktidarı, savaş sayesinde servetlerini büyük oranda artırmış olan sermaye sahiplerine yönelmiştir. Bu yönelimin bir sonucu olarak çıkarılan Varlık Vergisi, hem uygulanışı sırasında hem de sonraki süreçte ciddi tartışmaların konusu olmuştur. Verginin ağır olması ve toplanışı sırasında çeşitli uygulama sıkıntıları yaşanmasına rağmen, bu verginin şartların bir zorlamasının sonucu olarak yürürlük bulmuş olduğu kabul edilmelidir. Bu çalışmada; II. Dünya Savaşı öncesi ve sırasında Türkiye ekonomisinin genel karakteri tahlil edilmiş, bu çıkarımlara dayanılarak Varlık Vergisinin uygulanması gerekçeleri belirlenmiş, uygulama sürecinde ve sonrasında yaşanan gelişmeler değerlendirilmiştir.

Anahtar Kelimeler: Varlık Vergisi. II.Dünya Savaşı. Türkiye Ekonomisi

\section{Giriş}

Varlık Vergisi uygulaması İkinci Dünya Savaşı́nın Türkiye'deki yansımaları içerisinde öne çıkmış olan ve tartışılan bir konudur. Konuyla ilgili bu güne kadar kaleme alınmış olan çalışmalar içerisinde tarafsız bir bakış açısı sergilenmesi konusunda çeşitli sıkıntılar yaşanmıştır. Bu çalışma, temel kaynaklar önceliğinde konuyu aydınlatmak ve anlatmak amacı taşımaktadır. Verginin daha iyi anlaşılabilmesi için öncelikli olarak; Türkiye Cumhuriyeti Devleti'nin İkinci Dünya Savaşı öncesindeki ve savaş içerisindeki ekonomik çehresini iyi analiz etmek gerekmektedir. Vergi uygulaması ve sonuçları, bu değerlendirmeler dikkate alınacak şekilde sunulacaktır.

* Sabit DOKUYAN, Yard.Doç.Dr; Düzce Üniversitesi Fen-Edebiyat Fakültesi, Tarih Bölümü, sabitdokuyan@gmail.com 


\section{Sabit DOKUYAN}

Büyük sıkıntılar ve mücadeleler sonrası kurulmuş olan Türkiye Cumhuriyeti Devleti, bağımsızığının tam manasıyla teşekkül edebilmesi adına, ekonomik anlamada da güçlü olabilmenin yollarını aramıştır. Bu arayış, ülkenin içinde bulunduğu olumsuz şartlar itibariyle, gerçekleşmesi zaman alacak hedefler arasında yerini almıştır. Devlet, kuruluşunun ilk yedi yılında beklenen ekonomik atılımları tam manasıyla gerçekleştirememiş ve ağır aksak ilerleyen bir ekonomi ile idare etmeye çalışmıştır (Karpat, 2008, 187). Devletin kuruluş aşamasının devam ettiği süreçte, 17 Şubat 1923 tarihinde, İzmir iktisat Kongresi toplanmıştır ve ekonomide liberal bir politika izlenmesi için Misak-ı İktisadi Kararları kabul edilmiştir (Ökçün, 1968, 387-389). Kabul edilen kararların doğal bir sonucu olarak devlet, 1923 ile 1933 yılları arasında, ekonomik teşebbüslerin içerisinde çok fazla yer almamıştır. Özel yatıımcıyı harekete geçirmek adına Türkiye Sanayi ve Maadin Bankası(10 Nisan 1925) kurulmuş ve ardından 28 Mayıs 1927 tarihinde Teşvik-i Sanayi Kanunu'nu çıkarılmıştır (Güner, 1978, 13-14; RG, 15 Haziran 1927, 1). Fakat Osmanlı Devleti döneminde halk, daha çok askerlik ve tarımla uğraştığı için sanayi ve iş kolları, kapitülasyonların da etkisiyle, azınlıkların ve yabancıların eline geçmişti. Bu nedenle, Cumhuriyetin ilanı ile birlikte, sıfırdan bir özel sermaye sınıfı oluşturulmaya çalışılmıştır. Ülke genelinde mevcut bulunan azınlıklardan oluşmuş küçük sanayi erbabı ise 1924 yılında Yunanistan'la yapılan nüfus mübadelesiyle büyük oranda Türkiye'den ayrılmak durumunda kalmışırı. Yabancı unsurlara, ticaret alanında getirilen kıııtlamalar da işadamları sayısını oldukça düşürmüştür. Devletin kendi sermayedarını destekleyici uygulamalarına rağmen 1933 yılına kadar kuvvetli bir özel sermaye grubu ortaya çıkamamıştır (Serin, 1963, 227).

Özel sermayenin istenilen seviyeye ulaşmaması ve ardından tüm dünyayı etkileyen 1929 ekonomik krizi işleri daha da kötüye götürmüştür. Böylece devletin ekonomi içerisindeki yeri ve etkinliği hızlı bir şekilde artış göstermeye başlamıştır. Devlet, başıboş ilerleyen bir devletçilik anlayışıyla her alana girmeye başlamıştır; çiftlikler kurmuş, ormanclık, madencilik, dericilik, kağıt, tekstil, sigara, alkol, toprak ürünleri, gaz ve kömür dağıtımı gibi bir çok işletme alanına geniş bir oranda dahil olmuştur. Teoride özel teşebbüse büyük imkanlar sunulacağı belirtilse de uygulamada bu anlayış büyük oranda tahdit edilmiştir (Karpat, 2008, 187-189).

1933-1950 yılları arasında geçen sürede devletçilik, Türk ekonomisinin en güçlü uygulama şekli olduğu gibi, aynı yıllarda dünyanın birçok yerinde de ekonomide devletçilik uygulamaları ciddi manada tercih edilmiş̧ir. Amerika'da devletçilik uygulamaları görülmüştür ve ABD Başkanı Franklin Roosevelt, bankaları belirli seviyelerde devletleştirerek, bankaların verdikleri kredileri denetlemiştir. İngiltere'de de ABD benzeri bir devletçilik anlayışı uygulanmıştır. Rusya ise devletçiliğin en yoğun modelini hayata geçirerek önemli gelişme rakamları elde etmiştir. Rusya'nın bu hızlı yükselişi Türkiye'yi, ekonomide uygulayacağı anlayış konusunda yönlendiren önemli unsurlar arasında yer almıştır(Acar, 1999, 43-44). Fakat Türkiye, uygulama aşamasında, devletçiliğin sınırlarını kimi zaman doğru belirleyememiş ve bunun sonucu olarak da zamanla büyüyen özel sermaye ile çeşitli çatışmalar içerisine girmiştir (Ahmad, 2010, 159).

Kuvvetli devletçilik anlayışı ile birlikte; 1933 yılından İkinci Dünya Savaşı́na kadar devam eden süreçte Türkiye, sanayisinin temellerini atmıştır. Devlet; mülkün, idarenin ve sermayenin büyük 
sahibi olarak yatırımlar yapmıştır. Birinci Beş Yıllık Sanayi Planı 1933 yılında uygulanmaya başlanmıştır. Plana göre 5 yıl içerisinde ipek, seramik, cam, çimento, demir, kâğıt ve pamuk gibi Türkiye'de bulunan sanayi hammaddelerine dayanan yatırımları önceliklendirecek şekilde fabrikalar kurulması hedeflenmiştir. Uygulama sürecinde hedeflerin çoğunluğuna ulaşılmıştır ve hatta belirlenen sanayi kollarını destekleyecek fabrikalar dahi kurulmuştur (Serin, 1963, 115-117). Bu çerçevede; Kayseri'de bez, İzmit'te kağıt, Nazilli'de basma, Bursa'da yün, Gemlik'te suni ipek, Karabük'te demir ve çelik fabrikaları açılmıştır (Güner, 1978, 226). 1935 yılında devletçilik CHP tüzüğüne eklenmiş ve 1937 yılında ise Anayasa'da yer almıştır. 1933'te sanayi hamlesini desteklemek adına Sümerbank ve 1935 'te yer altı kaynaklarının aktif kullanımının sağlanması için ise Etibank kurulmuştur. Aynı yıl Etibank'ın işlerini kolaylaştırmak için Maden Tetkik Arama Enstitüsü çalışmaya başlamıştır. Bu çalışmalara paralel olarak demir yollarının artırılması için de ciddi çalışmalar içerisine girilmiştir. Tarım alanlarında ise önemli yatırımlar yapılmamış, fiyat desteklemeleri ve demir yollarının gelişimi tarıma dolaylı katkı sağlayan hamleler olmuştur (Serin, 1963, 109-112). Yapılan yatırımların finansman ihtiyaçları iç ve dış kaynaklı olarak karşılanmaya çalışılışstır. 1934 yılında Rusya'dan 20 yıl vadeli ve faizsiz olarak alınan 8 milyon Dolarlık borç, dokuma sanayinde değerlendirilmiştir. 1938 yılında İngiltere'den alınan 13 milyon Sterlinlik borç ise Karabük Demir-Çelik işletmelerinin güçlendirilmesinde kullanılmıştır (Acar, 1999, 48).

Birinci Sanayi Planı́nın süresi dolmadan, 1936 yılında, 100 fabrika kurmayı amaçlayan ikincisi hazırlanmıştır. Bu planla; madencilik, taş kömürü, elektrik, yakacak, toprak, gıda, kimya, makine ve denizcilik alanlarında yatırım yapılması hedeflenmiştir. İkinci plan birincisine göre daha kapsamlı olmakla birlikte, özel sermaye işin daha da dışına itilmiştir (Serin, 1963, 118). íkinci Beş Yıllık Sanayi Planı, İkinci Dünya Savaşı́nın başlamasıyla birlikte uygulanma imkânı bulamamıştır.

İki savaş arası dönemde Türkiye'nin dış ticaret hareketliliği ise şu şekilde cereyan etmiştir: Birinci Dünya Savaşı'na kadar açık veren ithalat-ihracat dengesi, Cumhuriyet' in kuruluşuna değin aynı seyrini devam ettirmiştir. 1929 yılına kadar geçen zaman içerisinde Lozan Antlaşması'na göre eski gümrük resimleri muhafaza edilmiştir. Bu süreçte dış ticarette önemli artışlar görülmüştür. 1923 yılında 65.2 milyon Dolar olan ihracat, 1929 yılına gelindiğinde 119.4 milyon Dolar’a çıkmıştır. 1923 ylı ithalatı 11.4 milyon Dolar iken bu rakam 1929 yılında 197.2 milyon Dolar'a yükselmiştir. Bu süre içerisinde dış ticaret sürekli olarak açık vermiştir. 1929 yılı ekonomik buhranı ve Türkiye'nin yeni gümrük tarifelerini uygulamaya koymasıly ihracat ve ithalatta duraklama devresine girilmiştir. 1930 sonrasında ihracat ithalat rakamlarında, 1938 yılı hariç, hiç açık verilmemiştir. 1930-1938 yılları arasında ithalat-ihracat rakamları şu şekilde gerçekleşmiştir (Köksal ve İlkin, 1973, 29-33; Tokgöz, 1991, 75): 
Sabit DOKUYAN

Tablo 1. 1930-1938 Yılları Arasında Itthalat-ihracat Rakamları

\begin{tabular}{rrrr}
\hline \hline Yıllar & ihracat(milyon \$) & ithalat(milyon \$) & Fark (milyon \$) \\
\hline 1930 & 116,5 & 113,5 & 3,0 \\
1932 & 77,9 & 66,2 & 11,7 \\
1934 & 70,8 & 66,9 & 3,9 \\
1936 & 90,6 & 71,2 & 19,4 \\
1938 & 111,5 & 115,4 & $-3,9$ \\
\hline
\end{tabular}

\section{2. İkinci Dünya Savaşı Sırasında Türkiye Ekonomisi}

Cumhurbaşkanı Atatürk'ün son başbakanı Celal Bayar olmuştur. 1939 yılı Ocak ayında Bayar istifa etmiştir ve yerine Refik Saydam Hükümeti kurulmuştur (Durmuş, Akbıyık ve Özkaya , 2008, 328). Bu süreçte dünya büyük bir savaşın eşiğindedir. Türkiye yaklaşan savaşa tam manasıyla hazırlanamamıştır. Başta Almanya olmak üzere birçok Avrupa devleti ise savaş hazırlıklarını süratle devam ettirmişlerdir. Türkiye, patlak veren savaşın dışında kalmış ama her an savaşa girme tehlikesi karşısında büyük miktarlarda askeri harcamalar yapmıştır. Ayrıca üretimi kısıtlı olan ülke, ithalatın da daralmasıyla, ciddi sıkıntıları derinden hissetmeye başlamıştır. Buğday, hububat ve bakliyat üretiminde savaşın başlangıcı ile bitişi arasında yarı yarıya bir azalma görülmüştür. Bu gelişmeler Türk ekonomisini yeni bir dengeye oturtma zorunluluğu doğurmuştur (Güneş, 2002, 615-617). Uygulanan savaş ekonomisi sürecinde iki milyon genç silah altına alınmış, bütçenin \%60’ askeri harcamalara ayrılmıştır. Halkın ihtiyaçlarını büyük oranda devlet teşebbüsleri karşılamıştır (Güner, 1978 , 45). Planlı ekonomi dönemi askeri harcamalar nedeniyle askıya alınmıştır. Böylece, iktisadi manada bir kesinti dönemi yaşanmıştır. Savaş öncesinde uygulanan aşırı müdahaleci ekonomi anlayışı, savaş sürecini de etkilemiştir ve geniş yetkilere sahip olan bürokrasi, savaş ekonomisi içinde bir baskı unsuru olarak ortaya çıkmıştır (Tunçay, Koçak ve Özdemir, 1995, 304). O kadar ki, özel sermayeye verilen teşvik yeterli bulunarak Teşvik-i Sanayi Kanunu 1942 yılında kaldırılmış, devletçilik anlayışı katı bir biçimde uygulanmıştır (Hiç, 2002, 544). Bu süreçte Türkiye ekonomisi; içine kapanık, kendine yetmeye çalışan, dış ekonomik ilişkileri sınırı bir hâl almıştır (Parasız, 1998, 59).

İkinci Dünya Savaşı'nın başlamasının ardından, 1930'larda uygulanan sıkı para politikalarından da vazgeçilmiştir. Para arzında büyük artış gerçekleşmiş ve savaşın getirmiş olduğu olağanüstü harcamalar için emisyon kullanılmıştır. Para arzındaki hızı artış, bu artışı karşılayacak düzeyde üretim gerçekleşmediğinden dolayı yüksek enflasyona neden olmuştur. İthalatın azalması, mal kıtıklarının yaşanması ve ulaşım-dağıtım düzensizliği de yaşananlara eklenince iktidar, ekonomik politika üzerindeki etkinliğini kaybetmiştir (Coşar, 2004, 98). Piyasadaki para miktarının artışının daha iyi anlaşılması için 1938 ile 1942 yılları karşılaştııılacak olursa; 1938 yılında piyasadaki banknot miktarı 
193,979 lira iken (Köklü, 1947, 48), bu miktar 1942 yılında 765.5 milyon liraya yükselmiştir (Başbakanlık İstatistik Genel Müdürlüğü, 1950, 230).

Savaş sürecinde toplanan vergi miktarları ve türleri artııımış, kısa vadeli bonolarla devlet halka borçlanmış, dar ve sabit gelirliler için sıkıntıı bir süreç başlamıştır ( Sevim, 1978, 282). Merkez Bankası imkânları savaşın ilk yıllarında büyük oranda kullanılmışır. Dış borçlanma konusunda da o döneme kadar sürdürülen önleyici tedbirler terk edilmiştir. Borçlanma, devletin normal ekonomik kalemleri arasında görülmeye başlanmıştır. Bütçe 1939 yılında açık vermiş, 1940-1943 arasındaki bütçe ise denk olarak planlanmış ama uygulamada fazla vermiştir. 1944-45 bütçeleri ise onaylanırken ve de uygulamada açık vermiştir. Böylece savaş öncesinde kontrol altında tutulan bütçe, savaş giderlerinin artması ile birlikte kontrolden çıkmaya başlamıştır. 1944 yılından itibaren bütçeler artık açık verecek şekilde onaylanmaya başlanmıştır. Açıklar, geçici tedbirlerle kapatılamamıştır (Coşar, 2004, 128-131).

Türkiye, dış ticaretini savaş yıllarında, dünyanın diğer ülkelerinde olduğu gibi, güçlükle yürütmüştür. illgili yıllarda dış ticaret dengesi ortalama olarak hep fazla vermiştir. Savaşa girmeyen Türkiye, savaşan ülkelerin ihtiyaç duyduğu ürünleri sağladığı için ihracatta bir artış yaşamış, fakat ithal edilecek malları üreten ülkelerin kendi intiyaçlarını ancak karşılaması sonrasında ise ithalatta ciddi bir daralmayla karşılaşmıştır. Fakat ihraç mallarının fiyatlarına nazaran ithal mallarının fiyatları daha fazla arttığı için, artan ihracattan beklenen yüksek kârlar elde edilememiştir. 1946 yılı ihracat fazlası verilen son yıl olmuştur (Serin, 1975, 22). Savaş yılları ve ardından gelen dönemde Türkiye'nin ithalat-ihracat rakamları şu şekilde gerçekleşmiştir (Köksal ve Ilkin, 1973, 33 ve 35; Tokgöz, , 1991, 75):

Tablo 2. 1940-1950 Yılları Arasında Türkiye'nin Ithalat-ihracat Rakamları

\begin{tabular}{lrrr}
\hline \hline Yıllar & ihracat(milyon \$) & ithalat(milyon \$) & Fark (milyon \$) \\
\hline 1940 & 87,7 & 53,0 & 34,7 \\
1942 & 126,9 & 113,6 & 13,3 \\
1945 & 168,4 & 97,1 & 71,3 \\
1946 & 184,6 & 137,4 & 47,2 \\
1947 & 223,3 & 244,6 & $-21,3$ \\
1948 & 196,8 & 275,4 & $-78,6$ \\
1949 & 247,8 & 290,1 & $-42,3$ \\
1950 & 263,4 & 285,7 & $-22,3$ \\
\hline
\end{tabular}

Savaş sırasında sanayi sektöründe bir gerileme yaşanmıştır. Sanayide yatııımlar azalmıştır ve özel sektörde istihdam düşmüştür (Ekzen, 1980, 12). Devlet elinde bulunan sektörlerde daha az bir daralma yaşanmıştır. Ticarette ise sanayi ürünlerinden çok tarım ürünleri pazarlanmıştır. Sanayi 
ürünlerinin fiyat artışları tarım ürünlerinin artışının çok gerisinde kalmıştır. Buğday ve tütün fiyatları aşırı derecede artmıştır ve bu durum tüccar için önemli bir kâr kapısı olmuştur. Maaşların milli gelirdeki payı önce \%10 civarına yükselmiştir. Ama artan enflasyon sonucunda 1942 yılında \%7.4'e, 1943 yılında ise \%5.3'e düşmüştür. İş̧̧i sınıfında ise sanayi üretiminin daralmasıyla ücretlerde \% 50'ye varan oranlarda düşüşler gerçekleşmiştir. Bu düşüş 1943 ylından itibaren yeniden bir toparlanma sürecine girmiştir (Tunçay vd., 1995, 307-310). Savaş yıllarında yabancı malların ithali azalınca, Türk malları karşısında yabancı malların rekabeti de ortadan kalkmıştır. Aynı yıllarda, başta demiryolları olmak üzere, yabancı işletmelerin millileştirilmesine ise devam edilmiştir. Dış dünya ile bağlantısı bozulan ya da kopan yabancı işletmeler zor duruma düşmüşlerdir (Rozaliyev, 1978, 188189).

Dünya Savaşı sürecinde Türk halkının genel profili ise şu şekilde olmuştur; küçük bir grup kolay kazanıp lüks yaşarken, toplumun büyük kısmı ise az gelirli köylü, iş̧̧i ve memurlardan oluşmuştur. Geçim sağlamanın ötesinde yiyecek bulma konusunda dahi sıkıntı çekilen savaş yıllarında; tifüs, verem, zafiyet gibi hastalıklar yaygın olarak görülmüştür (Çavdar, 2003, 310). Halk kıtlık korkusuyla tüketim mallarına hücum edince bir arz-talep dengesizliği ortaya çıkmıştır. Devlet, kendi ürettiği ürünlere sürekli zam ekleyince, piyasadaki diğer mallar da buna bağlı olarak fiyat artışına maruz kalmış ve karaborsacılık yaygınlaşmıştır (Akandere, 1998, 151-152). Hükümet 1942 yılı Ocak ayında vurgunculuğa ve karaborsacılığa karşı tedbir olarak 10 yıl hapis ve 10 bin lira para cezası getirmiştir. Vergi yükü ücretliler üzerinde yoğunlaşmış, bu kesim kazanç vergisinin yanı sıra iktisadi buhran, muvazene ve hava kuvvetlerine yardım adları altında çeşitli olağanüstü vergiler ödemek zorunda kalmışlardır. Zaten aldıkları ücretler enflasyon karşısında eriyen bu ücretli sınıf, gündelik ihtiyaçlarını karşılayamayacak konuma düşmüşlerdir (Coşar, 2004, 98 ve 104). Almanya, İngiltere ve ABD gibi güçlü ülkeler Türkiye'nin ürettiği hammaddeleri yüksek fiyatlarla satın alarak Türk tüccarı, sanayicisi ve toprak ağasını oldukça zenginleştirmişlerdir (Rozaliyev, 1978, 188).

Savaş döneminde sırasıyla hükümet kuran Refik Saydam ve Şükrü Saraçoğlu, ekonominin içinde bulunduğu sıkıntılı durumlarla baş edebilme gayreti içerisine girmişlerdir. Savaş başladığında başbakan olarak görev yapan Saydam, aldığı sert tedbirlerle ekonomik gidişatı kontrol altına almaya çalışmıştır (Metintaş ve Kayıran, 2008, 175). Bu hükümet döneminde ekonomiyi düzene sokmak amaçlı olarak Milli Korunma Kanunu çıkarılmıştır. 18 Ocak 1940 tarihli ve 3780 sayılı bu kanun, öncelikli olarak kolay yoldan kazanç elde edenlerle mücadele etmeyi amaçlamıştır. 72 maddeden meydana gelen bu kanun içerisinde: Halkın yararı ve müdafaa intiyaçları için üretim alanlarının hükümet tarafından denetlenip yönlendirilebileceği, üretim alanında çalışanların mazeretsiz olarak işlerine ara veremeyecekleri, üretilen mamullerin hükümetin belirleyeceği fiyatlarla devlete satılacağı, stokçuluğa karşı el koyma işlemlerinin gerçekleştirilebileceği, atıl durumdaki işyerlerinin hükümet tarafından işletilebileceği, şahısların ellerindeki alet ve makinelere bedeli karşılığında el konulabileceği, iş̧̧ilerin çalışma sürelerinin artırılabileceği, ithalatta kısıtlamalara gidilebileceği, ihracatın hükümet tarafından düzenleneceği, kira fiyatlarının artırılamayacağı, yüksek fiyat artışlarının denetleneceği, ziraat işgücünün devlet tarafından bedeni yükümlülükle başka yerlerde çalıştı- 
rılabileceği, belirlenen bu kurallara uymayanların ise çeşitli para ve hapis cezalarıyla cezalandırılacağı gibi maddeler yer almıştır (TBMMZC, 18 Ocak 1940, 139-158). Çıkarılan kanun 17 Mart 1940 tarihinde yürürlüğe girmiştir (TBMMZC, 18 Mart 1940, 4).

Kanuna bağlı olarak ilk etapta, 6 Aralık 1940 tarihinde, çiftçilerin ellerindeki hububatı devlete satması kararı çıkarılmıştır. Bu şekilde fiyat artışını sınırlandırmak amaçlanmıştır (Vatan, 6 Aralık 1940, 1). 12 Şubat 1941 tarihinde ise çiftçilerin stoklarındaki tohum ve yemekliklere el konulmasının yolunu açan kararname yayınlanmıştır. Halkın ihtiyacı olan un stokları oluşturabilmek için ise 30 Ocak 1941 tarihinde Toprak Mahsulleri Ofisi(TMO) sorumlu tutulmuştur (RG, 14 Şubat 1941, 1-3). 1942 yıı Ocak ayında ise pasta, çörek ve bunlara benzer mamullerin yapılması ve satılması yasaklanmıştır (RG, 30 Ocak 1942, 3). Hububat ve un stoku için alımlara başlayan TMO, üreticinin elindeki ürünleri piyasa fiyatının altında toplamıştır. Büyük fedakârlıklar ve zorluklar içerisinde ürünlerini devlete satan köylü, piyasadaki ürünleri yüksek fiyattan almaya başlayınca bu durum hoşnutsuzluklar meydana getirmiştir (Ünal, 1994, 20).

Kanununa bağlı olarak birçok fabrikaya, tesise (Yetim, 2006, 86-91), kamyona, gemiye, tankere, jeneratöre el konulmuştur (Akandere, 1998, 190). Nakil vasıtalarının seyrüseferi kısıtlanmıştır ve her bir taksinin iki günde bir çalışmasına izin verilmiştir (Yetim, 2006, 99). Resmi Gazete hariç olmak üzere diğer gazetelerin ebatlarına ve sayfa sayılarına da sınırlama getirilmiştir (RG, 10 Temmuz 1940, 11). Ticaret erbabının vergi kaçırmasını ve yüksek fiyattan mal satmasını engellemek amacıyla ise 5 Mart 1940 tarihli Bakanlar Kurulu kararıyla fatura kesme zorunluluğu getirilmiştir (BCA, 30..18.1.2/90.23..1.). Diğer bir uygulama olarak ise zorunlu çalışma yükümlülüğü yürürlüğe girmiştir. Bu uygulama, ziraatta çalışan kadın ve erkeğin, kendi işlerini aksatmamak kaydıyla, yaşadıkları yerin $15 \mathrm{~km}$ çevresinde bulunan devlet ya da şahıslara ait işletmelerde uygun ücretle çalıştırılabilmesi mecburiyeti şeklinde olmuştur (Akandere, 1998, 193-195). İ̧̧ mükellefiyetine tabi tutulanların; hastalık, doğal afet ya da ikinci dereceye kadar akrabalarından birisinin ölümü dışında hiçbir mazeretleri kabul görmemiştir (RG, 5 Ocak 1943, 2).

1942 yılında Refik Saydam'ın ani ölümü üzerine iktidara gelen Şükrü Saraçoğlu Hükümeti, Milli Korunma Kanunu temelinde yürüyen sıkı ekonomik önlemlerde yumuşamaya gitmiştir. Öncelikle fiyatlar serbest bırakılmıştır (Coşar, 2004, 99-100). Çiftçinin mallarına el koymaya da sınırlama getirilmiş ve \%25 uygulaması adı verilen yeni bir sistem kullanılmıştır. Böylece 50 tona kadar ürünü olan çiftçinin sadece $\% 25$ ürününe el konulmuştur. Bunun üzerindeki miktarlar için ise $\% 35$ ve $\% 50$ seviyelerinde el koyma işlemi gerçekleşmiştir (Kayıran, 1995, 164-166; Çavdar, 2003, 313). Fakat bu uygulama sonrasında çiftçinin elinde kalan ürünlerin serbest piyasaysa sürülmesiyle fiyatlar daha da artmıştır (Ekzen, 1980, 13; Parasız, 1998, 61). Hükümet çiftçiyi biraz rahatlatmak adına Ziraat Bankası aracılığıyla tohumluk dağııımı başlatılmıştır (RG, 5 Kasım 1943, 1). 1944 yılında ise Milli Korunma Kanunu hükümlerine göre 1942 yılı hububat borcunu ödeyemeyenlerin borçları affedilmiştir (TBMMZC, 26 Ocak 1944, 140). 1 Kasım 1944 tarihinde de pasta, çörek, simit, bisküvi, börek, baklava gibi hamur işlerinin üretilmesine izin verilmiştir (RG, 1 Kasım 1944, 1). Yeni hükümet ekonomik serbestliğe doğru adımlar atmış olsa da, kimi zaman savaş şartlarının bir gereği olarak, katı uygulamalar da yürürlüğe sokmak durumunda kalmıştır. Acil ihtiyaç duyulan ürünlere el koyma bu 


\section{Sabit DOKUYAN}

tip uygulamalar arasında yer almıştır (BCA, 30..18.1.2/109.55..2.). Savaş içerisinde halk tarafından büyük tepki toplayan Milli Korunma Kanunu, CHP'li vekiller tarafından, savaş sonrası dönemde, kanunun bir gereklilik sebebiyle uygulandığı açıklamalarıyla savunulduğu görülmüştür. Kanun sayesinde kıtlığın önüne geçildiği ve savaş şartlarının getireceği büyük bir yıkımın engellendiği iddia edilmiştir (BCA, 490..1.0.0/5.26..30.).

Savaşın ekonomik anlamdaki diğer bir yansıması ise ekmek karnesi uygulamasında kendisini göstermiştir. İlk etapta 18 Şubat 1941 tarihinde İstanbul, İzmir ve Ankara'da tek tip ekmek uygulamasıyla başlatılan ekmekle ilgili önlemler (RG, 21 Şubat 1941, 2) gerekli tasarrufu sağlamamış ve hükümet ekmek karnesi uygulamasına geçmek zorunda kalmıştır (Özkan ve Temizer, 2009, 319325). Öncelikle İstanbul'da, 11 Ocak 1942 tarihinde, ekmeğin alınacağı karneler dağıtılmıştır (Cumhuriyet, 12 Ocak 1942, 1) ve 14 Ocak günü de ekmekler karneyle alınmaya başlamıştır (Cumhuriyet, 14 Ocak 1942, 1). 17 Ocak 1942 günü de Ankara'da ekmek karnesi dağıtımı başlatılmıştır (Ulus, 17 Ocak 1942, 1). Kısa sürede tüm yurda yayılan uygulamaya göre 7 yaş altı çocuklara 187.5, 7 yaş üstü kişilere 375, ağır işçilere 750 gram günlük ekmek alabilme izni verilmiştir (Çınar, 2008, 241242). Zaman içerisinde bu gramajlarda çeşitli değişiklikler ve çoğunlukla da azaltmalar gerçekleştirilmiştir. Askerler için verilen ekmeğin gramı artırılırken(TBMMZC, 2 Şubat 1942, 240), halk için dağıtılan ekmeklerde ise genelde eksiltmeye gidilmiştir(Karabekir, 2009, 1252; Ulus, 28 Şubat 1942, 1). Kimi zaman da bir gün tam bir gün eksik ekmek verme uygulaması hayata geçirilmiştir (Karabekir, 2009, 1262; İnönü, 2008, 324). Zaman içerisinde hububat konusundaki rahatlamalara bağı olarak ekmeğin gramajının artırıması ve içerisindeki katkı maddelerinin azaltılması çalışmaları gerçekleşmiştir (Son Telgraf, 3 Haziran 1942, 1). Ekmek karnesi uygulaması savaşın sona ermesi ile birlikte hükmünü yitirmiş, 9 Eylül 1946 tarihli bir genelgeyle de karne ile ekmek satışı tamamen sonlandırılmıştır (Tanin, 9 Eylül 1946, 1; Vatan, 9 Eylül 1946, 1).

Diğer bir savaş ekonomisi uygulaması ise 4 Haziran 1943 tarihinde kabul edilmiş bulunan Toprak Mahsulleri Vergisi olmuştur (Kolaç, 2002, 674). 26 Nisan 1944 tarihinde vergi miktarı \%8 den \%10’a çıkarılmıştır (Kayıran, 1995, 168). Toprak Mahsulleri Vergisi daha çok küçük çiftçiyi mağdur etmiştir. Alınacak ayni vergi, ürün daha tarladayken, göz kararıyla belirlendiği için çoğu zaman, gerçek vergi rakamlarının üzerinde vergi tarh edilerek çiftçi mağdur edilmiştir. Verginin belirlenen merkezlere çiftçi tarafından götürülmesi, kimi memurların rüşvet istekleri de vatandaşı zorlamıştır (Akandere, 1998, 169-170). Vergi dahilinde 229.130 .214 lira toplanmıştır (Ökte, 1951, 201). Milli savunma giderleri için çıkarılan vergi, savaşın ardından, 23 Ocak 1946 tarihinde sonlandırımıştır (TBMMTD, 23 Ocak 1946, 91-92).

\section{Varlık Vergisine Giden Yol ve Verginin Yürürlüğe Girişi}

Çeşitli vergilendirmeler ve getirilen yükümlülüklerle halk üzerinde büyük bir baskının oluşturulduğu savaş döneminde, küçük bir azınlık grup gereğinden fazla bir özgürlüğü yaşamıştır. Devlet üretimde; hammaddeleri mamul ve yarı mamul haline getirmiş, dağıtım işi ise devlet kontrolü dışında cereyan etmiştir. İthalat ve ihracat işi de devlet kontrolünde özel işletmelere devredilmişti 
(Karpat, 2008, 190). Büyük devletlerin Türk ihraç malları olan krom, bakır filizleri, pamuk, yün, deri, tütün ve tahıl gibi ürünlere yüksek fiyatlar vererek satın almaları, Türkiye'deki tüccar, büyük sanayici ve toprak ağalarının zenginliklerini daha da artırmıştır (Rozaliyev, 1978, 188). Çiftçiler çoğunlukla Müslümanken, tüccarlar ve sanayiciler ise çoğunlukla Rum, Yahudi ya da Ermenilerden teşekkül etmiştir (Lewis, 1996, 296).

Elde ettikleri gelirlerle zenginleşen küçük sermayedarlar, özel tüketimleri için daha fazla mamul taleplerinde bulunmaya başlamışlardır. Bahsi geçen kişilerin taleplerini karşılayacak ve bu küçük sınıfın ihtiyaçlarına hitap edecek şekilde üretim yapan işletmeler ortaya çıkmıştır. Daha ucuza mâl ettikleri ürünleri, devletin belirlediği yüksek fiyatlara endeksli satan bu işletmeler büyük kârlar elde etmişlerdir. Bu grup; ithal malların stoklanması, karaborsa ve devletten kaçırılan malların satışlarından da olağanüstü kârlar sağlamışlardır. Süreç, özel sermayenin büyük birikimler ve yatırımlar yapmasına (ev, arsa, dükkan, altın) imkan sağlamıştır. Vergilendirme usulü de bu kesimi rahatlatmıştır. Maaşlardan yapılan vergi kesintisi hiç aksatılmazken, zengin sınıf çok az vergi vermiştir (Karpat, 2008, 191-194). Saraçoğlu Hükümeti'nin piyasa denetimini zayıflatması, kolay yoldan para kazananların işlerini daha da kolaylaştırmıştır. Gittikçe artan haksız kazanç vatandaşın vicdanını yaralamıştır (Çavdar, 2003, 319-320). Bu durum, ekonomik yönden birbirinden kopuk iki sınıfın ortaya çıkmasına neden olmuştur. Bir tarafta kolayca servet biriktiren küçük bir grup yer alırken, diğer tarafta; küçük tarım ve mamul üreticisi, maaşla geçimini sağlamaya çalışan işçiler ve memurlardan oluşan büyük bir sınıf yer almıştır. Çoğunluğu oluşturan ve sıkıntı içerisindeki vatandaş, gündelik ihtiyaçlarını dahi karşılayabilmekte büyük güçlükler çekmiştir (Çavdar, 2003, 310).

İktidarın ekonomiyi düzenlemek için almış olduğu tedbirlerin işe yaramamış olması, beklenen enflasyon ve fiyat düşüklüğünün gerçekleşmemesi dikkatleri bir anda lüks yaşayan küçük sınıfın üzerine toplamıştır. Bu kimselerin ellerindeki büyük sermayenin vergilendirilmesi düşünülmeye başlanmıştır. Savaş sırasında birçok ülkede uygulanan şekliyle bir kazanç vergisi konulması düşüncesi çeşitli çevrelerde sıkça dillendirilmiştir. Bu düşünce aynı zamanda azınlıklar lehine işleyen bir ekonomik sistemin değiştirilmesi adına fırsat sayılmıştır. Yabancılar, Osmanlı'dan kalma bir gelenekle, ticari işleri azınlık unsurlarla gerçekleştirmeye devam etmişlerdir. Bu sınıf, Türk iş dünyasının yetersizliğini öne sürerek tekellerinde buluna ithalat-ihracat gücünü sürekli hale getirmişlerdir ve yerli unsurları saf dışı bırakmışlardır. Bahsi geçen anlayış, konulacak verginin haklı bir gerekçesi olarak ortaya çıkmıştır (Coşar, 2004, 99-100 ve 103).

Savaşın ağır yükü altında çırpınan Türkiye ekonomisinin bir nebze de olsa ferahlaması adına yeni bir vergi konulması düşüncesi 1942 yılı sonbahar aylarında iyiden iyiye gündeme oturmuştur. Basın ve siyasetçiler konunun gündemde kalması için çaba sarf ederek bir altyapı oluşturmaya çalışmışlardır. Öncelikli olarak zenginlerin, savaş sırasında fedakârlıklar yaparak ekonomiye katkı sağlamaları algısı yaratılmaya çalışıımışır. Vatan Gazetesi'nin 4 Kasım 1942 tarihli baskısında, özellikle İstanbul zenginlerine hitap edilerek; namuslu her vatandaşın yapması gerektiği gibi zengin İstanbulluların kesenin ağzını açması gerektiği belirtilmiş̧ir. İstanbul Ticaret Odası'nın 200.000 lira bağışlayarak bu meblağın fakirlere ulaştırımasını istemesini olumlu bir hareket olarak gören gaze- 
te, diğer zenginlerin de az ya da çok bu yolu takip etmelerini telkin etmiştir (Vatan, 4 Kasım 1942, 1).

Dönemin Cumhurbaşkanı İnönü ve Başbakanı Saraçoğlu da vergi konusunu konuşmalarında dillendirmeye başlamışlardır. 1 Kasım 1942 günü meclis yasama yılı açılışında konuşan İnönü; ticaretteki şuursuz havanın ve mevcut sebepler dairesini fazlaca aşan fiyatların büyük sorun oluşturduğunu belirtmiş, bu konularda en uygun tedbirlerin alınacağını ifade etmiştir. Cumhurbaşkanı; içinde bulunulan ortamı fırsat bilen çiftlik ağalarının, her şeyi ticarete döken tüccarların, bu sıkıntıları fırsat kabul eden bazı siyasetçilerin memleketin zarına çalışmakta olduklarını, bu tip insanlara asla müsaade edilmeyeceğini ve gereken tedbirlerin en kısa zamanda alınacağını söyleyerek konuşmasının bir yerinde şu net ifadeleri kullanmıştır: “...Vatandaşların selametine aykırı olarak, doğru ve kanaatli yoldan sapacaklara, bulanık zamandan siyaset veya ticaret kârı arayacaklara, kesin, kâti olarak karşı koyacağız... (TBMMZC, 1 Kasım 1942, 4; İnönü, 1946, 368)."

10 Kasım 1942 tarihli CHP parti grubu toplantısında konuşan Saraçoğlu ise; içinde bulunulan mevcut durumdaki yüksek eşya fiyatlarının temelinde üretimin azlığının, ithalat eksikliğinin, alınan yanlış ekonomik tedbirlerin, doymak bilmeyen kazanma hırsının ve ihtikârın önemli bir yere sahip olduğunu belirtmiştir. Başbakanın aktardığına göre; tedavüldeki Türk parasının miktarı da artmıştır. 700 milyon liraya yaklaşan piyasadaki paranın bir miktarının vergi olarak geri çekilmesi gerekmektedir. Bu işlem de daha çok, savaş yıllarında çok fazla para kazanmış olanlar aracılığıyla gerçekleşecektir (Barutçu, 2001, 593).

Bir savaş vergisi olarak ve sadece yüksek kazançlı kimselerden alınması planlanan vergi ile ilgili görüşmeler 11 Kasım 1942 tarihli meclis oturumunda gerçekleşmiştir. Vergi görüşmeleri öncesinde ülkenin ekonomik durumunu değerlendiren Başbakan Saraçoğlu özetle şu ifadeleri kullanmıştır: Savaşın birinci yılında ülke mevcut stoklar ve ithal malların varlığı ile rahat etmiştir. Bu yıl içerisinde yaşanan en büyük ekonomik darbe gençlerin savaş tehlikesi karşısında silah altına alınmış olmasıdır. Savaşın ikinci ve üçüncü yıllarında ürünlerdeki azalma hissedilmeye başlanmıştır. İthalat daralmış, genç nüfusun askerde olması üretimi azaltırken, tüketimi artırmıştır. İhtikâr artış göstermiş ve Refik Saydam Hükümeti bu uygulamayla ve artan fiyatlarla mücadeleye girişmiştir. Fakat alınan sıkı tedbirler ve mallara el koyma uygulamaları gereken rahatlamayı gerçekleştirememiştir. Şimdiki hükümet ise bir kısım sert uygulamalarda yumuşamalara gitmiştir. Hatta bazı katı uygulamaları kaldırarak yeni bir çözüm yolu denemeye başlamıştır. Lakin alınan tedbirlere rağmen ithal malların fiyat denetimi hükümetin kontrolüne geçememiştir. Bundan sonraki süreçte; haksız kazançla yükünü almış olanlar, gerçekten ve zorluklarla üretim yapanlardan ayrılarak kontrol altına alınmaya çalışılacaktır. Konulacak olan yeni vergi çoğunlukla savaş sırasında büyük kazançlar elde edenlerden alınacaktır. Bir kereye mahsus alınacak bu vergi tüccarlar, emlak sahipleri ve büyük toprak sahiplerinden tahsil edilecektir. Savaşın en büyük kâr sınıfı tüccarlar olduğu için en büyük vergi dilimi de onlara ayrılacaktır. Verginin tespitini altışar kişiden oluşan komisyonlar yapacaktır. Vergi, mükelleflerin paralarının gücünden yararlanarak suiistimallerde bulunacakları kaygısıyla kısa sürede (15 gün) tahsil edilecektir (TBMMZC, 11 Kasım 1942, 15-22). Başbakandan sonra söz alan Antalya 
Milletvekili Rasih Kaplan; Milli Mücadele sırasında, ülke zenginlerinin ve mal sahiplerinin ellerinden gelen bütün fedakârlıkları göstererek servetlerini bağışladıklarını ve konulan vergileri fazlasıyla ödediklerini hatırlatarak, yine aynı fedakârlığı ülkenin zenginlerinin bu süreçte de göstermeleri gerektiğini belirterek(TBMMZC, 11 Kasım 1942, 27) Tekâlifi Milliye Emirleri'ne atıfta bulunmuştur.

Konuşmaların ardından Varlık Vergisi Kanunu maddelerine geçilmiştir. Verginin maddelerinden önem arz edenler kısaca şu şekildedir: Vergi bir defaya mahsustur, servet ve kazanç sahiplerinin servetleri ve fevkalade kazançları üzerinden alınacaktır(Madde 1). Büyük çiftçiler, sahip oldukları binaların yıllık geliri 2.500 liradan fazla olanlar, sahip oldukları arsa değerleri 5.000 liradan fazla olanlar, 1939 senesinden beri 2395 sayılı Kazanç Vergisi (RG, 25 Mart 1934, 3) ve 2728 sayılı iktisadi Buhran Vergisi Kanunu'na Muzeyyel 2416 Saylı Kanunu Değiştiren Kanun'la (RG, 29 Mayıs 1935, 1) belirlenen işlerle uğraşanlar, Varlık Vergisi kanunu çıktıktan sonra işlerini devredenler yahut bırakanlar, meslekleri tacir, komisyoncu, tellal veya simsar olmadığı halde 1939 yılından beri bu yollarla bir defaya mahsus olsa bile kazanç elde edenler Varlık Vergisi'nin mükellefleri arasında olacaklardır(Madde 2). íkinci maddede belirtilen zümrelerden birden fazlasına dahil olanlar her biri için ayrı vergi vereceklerdir(Madde 3). Vergilendirme komisyonları mükelleflerin tahakkuk ettirilmiş olan bir önceki yıl vergilerini inceleyeceklerdir ama vergi tespitinde kendi kanaatlerini kullanacaklardır. Çiftçiler için belirlenecek vergi o kimselerin servetinin yüzde beşini geçmeyecektir. Vergi, büyük şirketlerin 1941 yılı gelirlerinin yüzde ellisinden aşağı, yüzde yetmişinden fazla olmayacaktır(Madde 6). Vergilerin tespiti için her vilayet ve kaza merkezinde, oranın en büyük mülki amiri başkanlığında; en büyük mal memuru, ticaret odaları ve belediye azalarından ikişer kişi olmak üzere 6 kişiden oluşan heyetler teşkil edilecektir. Komisyon kararları çoğunlukla verilecek ve eşitlik halinde reisin oyunun olduğu tarafın kararı kabul edilecektir(Madde 7). Komisyonlar, mükelleflerin mükellefiyet miktarlarını on beş gün içinde belirlemek durumundadırlar(Madde 9). Komisyon kararları şehir ve kasabalarda gelir dairelerinin kapılarına ve köylerde münasip yerlere asılarak duyurulacaktır. Kararlar katidir, idari ve adli mercilere itiraz yolu kapalıdır. Sadece mükerrer vergi konulmuşsa yüksek olan kabul edilip diğeri silinebilir(Madde 11). Mükellefler vergiyi on beş gün içerisinde mal sandığına yatıracaklardır. Bu süre beklenmeden bölgenin en büyük mal memuru, ihtiyaç duyarsa, mükellefin mallarına ihtiyaten el koyabilecektir. Zamanında ödenmeyen vergi için ilk gecikme haftasında yüzde bir, ikinci haftasında yüzde iki faiz uygulanacaktır. Bir ay sonunda borçlarını ödemeyenler, askeri işler dışında, belediye ve ya umum hizmetinde bedeni olarak çalıştırılacaklardır. Kadınlar ve 55 yaşını geçmiş erkekler bu çalışmadan muaf tutulabilecektir. Çalışanlara verilecek yevmiyenin yarısı borçlarından düşülecektir(Madde 12). Büyük şirket ortakları da gerekirse zorunlu çalışma yükümlülüğüne tabi tutulabileceklerdir(Madde 13). Mükelleflerin ikametgâhlarında bulunan eş, kardeş, anne, baba ve çocuklarına ait gayrimenkul mallar da vergiye karşılık olarak satılabilecektir. Gayrimenkullerin sahibi tarafından satışı sırasında, bu malların Varlık Vergisi dahilinde olmadığı resmi olarak tespit edilmez ise yapılan satışlar tapu müdürlüklerince onaylanmayacaktır(Madde 14). Bu kanunun yürütmesinden Bakanlar Kurulu sorumludur(Madde 17) (TBMMZC, 11 Kasım 1942, 29-32). 
Sabit DOKUYAN

Vergi maddelerinin tek tek görüşülmesinin ardından yapılan oylamaya; mevcut 429 vekilden 350 tanesi iştirak etmiş ve katılanların tamamı olumlu rey vermiştir. Falih Rıfkı Atay, Tayfur Sökmen, Fethi Okyar, Reşat Nuri Güntekin, Hüseyin Cahit Yalçın, Atıf Tüzün, Abidin Daver, Ahmet Şükrü Esmer, Salah Cimcoz, Celal Bayar, Halil Menteşe, Hasan Ali Yücel, Mahmut Esat Bozkurt, Hüseyin Rahmi Gürpınar, Ali Canip Yöntem, Damar Arıkoğlu, Cevdet Kerim İncedayı oylamaya katılmayan vekillerden birkaçı olmuştur (TBMMZC, 11 Kasım 1942, 33-35). Kabul edilen Varlık Vergisi 17 madde olarak ve 4305 kanun numarasıyla 12 Kasım 1942 tarihinde Resmi Gazete'de yayınlanarak yürürlüğe girmiştir (RG, 12 Kasım 1942, 1-2).

\section{Verginin Uygulanış Süreci ve Bedeni Çalışma Yükümlülüğü}

Varlık Vergisi Kanunu çıkarılmadan önce, Maliye Bakanlığı tarafından defterdarlıklara gönderilen bir yazı ile; savaş sürecinde fevkalade kazançlar elde edildiği ve bu kazançların vergilendirilmediği belirtilerek, kısa süre içerisinde bu şekilde kazanç elde edenlerin tespit edildiği cetveller istenmiştir. Emir üzerine, İrat ve Servet Müdürlüğü, şubelerden konuyla ilgili malumatı toplamaya başlamıştır. Gelen cetveller içerisinde şahısların isimleri, adresleri, hangi işle meşgul oldukları, savaş öncesi ve son servet durumları yer almıştır. Bu cetveller Ankara'ya gönderilmiştir. Hazırlanan cetveller içerisindeki isimler öncelikli olarak Müslim(M) ve Gayrimüslim(G) olarak iki gruba ayrılmıştır. Sonraki süreçte bunlara Dönme(D) ve Ecnebi(E) sınıflandırmaları da eklenmiştir (Ökte, 1951, 4748). Yasa yürürlüğe girdikten sonra ise illerde komisyonlar oluşturularak vergi verecek olan kişiler ve vergi miktarları tespit edilmeye başlanmıştır (Kayra, 2011, 53).

Vergi tespiti işlemleri sırasında mükelleflerin sahip oldukları servetlerin miktarlarının hesaplanmasında büyük güçlükler yaşanmıştır. Özellikle yabancılar için vergi miktarının belirlenmesi sıkıntılar doğurmuştur. İstanbul Emniyet Müdürlüğü’nde yabancıların sadece ülkeye ilk girişinde verdikleri ikamet kayıtları mevcuttur. Fakat ikamet değişiklikleri zaman içerisinde takip edilmemiştir. İşyerleri konusunda da emniyette kayıtlar bulunmamaktadır. Vergi kayıtlarında da mükelleflerin tabiiyetleri hakkında bir bilgi mevcut değildir. Eldeki verilerle ecnebileri tespit etmekte büyük sıkıntılar cereyan etmiş̧ir. Bazı kişiler Türk vatandaşı zannedilmiş ama bu kişiler yabancı uyruklu çıkmışlardır. Nüfus ve konsolosluk kayıtlarının düzensizliği işi daha da zor bir hale sokmuştur (Ökte, 1951, 81-82). Vergi tahsili sırasında ise yabancılara ait gayrimenkullerin, bu kimselerin borçları karşlığında satışı sorun olmuş ama bu konu Bakanlar Kurulu'nun satışa izin vermesi kararıyla aşılmaya çalışılmıştır (BCA, 30..18.1.2/102.57..10.).

Vergi miktarlarının belirlenmesinin ardından hazırlanan vergi listeleri halka açıklanmıştır. Fakat kısa süre sonra şikayetler yağmaya başlamıştır. İstanbul, Bursa, Adana ve Hatay illeri en çok şikâyet gelen yerler olmuştur (Barutçu, 2001, 602). Mükellefler itiraz için vilayete, Maliye Bakanlığı'na, Başbakanlığa, Cumhurbaşkanlığına ve meclise dilekçeler yazmışlardır. Verginin çokluğu, hatalı vergi tayini, mükerrer vergi itirazı gibi konular öncelikli dilekçe yazma nedenleri arasında yer alıştır. Anayasaya göre bu dilekçelerin mutlak olarak cevaplandırılması gerekmiştir. Bu amaçla bir hukuk servisi oluşturulmuştur ve servis, maddi hatalar ve mükerrerlik konularında çalışmak üzere iki kaleme 
ayrılmıştır. Süreç içerisinde meclise 13.348, diğer mercilere de 10.968 dilekçe olmak üzere toplam 24.316 dilekçe verilmiştir (Ökte, 1951, 106 ve 110). Bu dilekçelere verilen cevaplara bir örnek olarak İzmir'den vergi mükellefi Bünyamin Nahum'un vergi miktarına itirazı sonrasında, Maliye BakanIı̆̆'nın verdiği cevabı gösterebiliriz. Bakanlık ilgili şahsın adına tespit edilmiş olan meblağ ile ilgili herhangi bir hata ve kanunsuzluk olmadığı tespitini, 10 Kasım 1943 tarihinde ilgili defterdarlığa bildirmiştir. Bu şahsın kendisine tahakkuk ettirilen vergiyi ödemesi gerektiği belirtilerek, Varlık Vergisi Kanunu'nun 2. maddesine göre bu şahsın 100.000 lira vergi ödeyeceği tasdik edilmiştir (BCA, 30..10.0.0/135.971..23.).

Vergisini ödemek isteyip de ödeyemediği için devlet kademelerinden yardım isteyen mükellefler de olmuştur; 13 Ocak ve 22 Ocak 1943 tarihlerinde İstanbul'da bulunan Cihan ve Kanaat Kitabevlerinin sahipleri Varlık Vergisi borçlarının karşılığı olarak ellerindeki kitapların satın alınması için Milli Eğitim Bakanlığı'na mektup yazmışlardır. Kanat Kitabevi'nin sahibi ilyas Bayar'ın mektubundaki ifadelerin özeti şu şekildedir: 1896 tarihinde açmış olduğum kütüphanemle 50 yıldır bu memleket insanına hizmet etmekteyim. Şimdi ise Milli Eğitim Bakanlı̆ı'’nın yardımını talep edecek bir hale geldim. Yardım talebimin sebebi üzerime düşen bir vazifeyi yerine getirmek içindir. Varlık Vergisi olarak tarafıma 494.500 lira tarh edilmiştir. Borcumun 250.000 lira kadarını ödemiş bulunmaktayım. Bu miktarı karşılayabilmek için sahip olduğum her şeyi sattım. Elimde sadece elli yıldan beri neşrettiğim kitaplarım kaldı. Bu kitaplar İngilizce-Türkçe Sözlük, Almanca-Türkçe Sözlük ve Türk tarihi ile ilgili bir kitaptır. Bankalar nazarında bir kıymete sahip olmayan bu kitaplarımın kıymetinin tespitini tarafınıza bırakıyorum. Tespit edilen fiyattan kitaplarımın alınmasını ve vergi borcuma karşılık olmasını tarafınızdan rica ve istirham ediyorum (BCA, 30..10.0.0/144.31..13.).

Diğer bir yardım talebi içeren ve Cihan Kitabevi sahibi Aramanuş Acun'un mektubu ise özetle şu şekildedir: Babam Mihran Acun tarafından kurulmuş olan Cihan Kitabevi'nde binlerce eser tâb ve neşrolunmuştur. Babamın devamı olarak Cumhuriyet adliyesine ve Milli Eğitim Bakanlığı'na hizmete devam ettim. Babam zamanında neşredilen Karakoç'a ait 16 ciltlik Sicilli Kavanin Külliyatı'nın devamı olarak 6 cilt de ben neşrettim. Savaş dolayısıyla kitapçı camiası durgunluk içerisindedir ve birçok sektörde olduğu gibi büyük kazançlar elde edememiştir. Cihan Kitabevi'ne Varlık Vergisi'nden 30.000 lira tarh edilmiştir. Kütüphanem ve dört odalı meskenim nakde çevrilse en fazla 8.000 lira eder. Tahakkukta maddi bir hata olduğu kanaatindeyim. Elimdeki kitapları ve kitap halinde olmayan formaları kesekâğıtçılara kilo ile satmam gerekecek. Ülkenin gençliği için önem arz eden bu kitapların kilo ile satılmasına gönlüm razı değildir ve en azından hükümet tarafından borcuma karşııı olarak satın alınmasını istemekteyim. Tarafıma yüklenen verginin 1.200 lirasını yatırdım. Borcumun makul seviyelere indirilmesi ve uzun bir zaman diliminde ödemem için imkan sağlanması ricamdır (BCA, 30..10.0.0/144.31..13.).

Vergilerin tahsili sırasında kimi zaman siyasetle yakın temasın nimetlerinden faydalanılarak indirimler ve aflar gelirken, kimi zaman da tam zıttı durumlar yaşanmış ve çekişmeler fazladan vergi yükü bindirilmesine neden olmuştur. Böylece adam kayırma ve iltimas, vergilendirme sürecinde de etkin olarak başvurulan bir yöntem olarak hayat bulmuştur (Coşar, 2004, 115). Bazan ise ellerinde imkân varken bunu kullanmayı uygun görmeyenlere de rastlanmıştır. Bu şekilde örnek bir olay, 


\section{Sabit DOKUYAN}

dönemin Genelkurmay Başkanı Mareşal Fevzi Çakmak'ın başından geçmiştir. Mareşalin Kadıköy'de bulunan ve eskiden ilkokul olan evine 2000.000 lira civarında vergi tarh edilmiştir. Çakmak, yaveri aracılığıyla teessüflerini bildirmiştir. Görevli memurlar ise verginin umuma yönelik olduğunu söylemiş, Çakmak da vergisini ödemiştir (Ökte, 1951, 178).

Verginin tahsil edilmeye başlamasından sonra, süreç içerisinde yaşanan sıkıntıları asgariye indirebilmek ve vergiyi en üst seviyede tahsil etmek adına, 7 Ocak 1943 tarihinde Bakanlar Kurulu tarafından bir kararname yayınlanmıştır. Yayınlanan kararla, tahsilâtın yapıldığı süreçte mükelleflerin tâbii tutulacakları muameleler sıralanmıştır. Buna göre: ilk on beş gün içinde vergisini ödeyen mükelleflere işlerini kolaylıkla devam ettirebilmeleri için bankalar ve ilgili müesseseler tarafından gereken kolaylıklar sağlanacaktır. İkinci on beş günlük süre içerisinde faizli olarak ödeme yapacak kişiler arasında mal kaçırma ihtimali olan kişilere ilgili kanunlar derhal uygulanacaktır. Bir aylık süre sonunda borcunu kısmen ya da tamamen ödemeyenler hakkında tahkikat başlatılacaktır. Bu süreçte; borçlarının en az yarısını ödemiş olanlar içinden mal kaçırma şüphesi olanlarla ilgili takibat derhal başlatılacaktır. Bu şekilde şüphe bulunmayanlardan; kalan borçları için teminat verebilenler ile satış ve kazançlarından borçlarını ödeyebileceklerine kanaat getirilenlere, teminat gerektirmeden, takibat 6 ay geciktirilebilecek ve çalışma yükümlülüğü tehir edilebilecektir. Vergisini yarısından az ödeyen veyahut hiç ödemeyenlerle ilgili kanun uygulaması derhal başlatılacaktır. Fakat sayının binlerle ifade edildiği düşünülerek, en büyük vergi sahiplerinden başlanarak işlemler sıraya konulacaktır. Mahalle bakkalları gibi sınırlı ve basit ticaretle uğraşanlar ile seyyar satıcılar ve müstahdemlerle ilgili olarak takibata girişilmeden önce ilgili bakanlıktan izin alınacaktır. Yukarıda bahsedilen konulardaki işlerin yürütülmesinde ve merkezle münasebetin sağlanmasında mal memurları ile mahallin en büyük idare amiri arasında mutabakat sağlanacaktır (BCA, 30..18.1.2/100.110..17.).

Vergisini ödeyemeyen ya da ödemek istemeyen kimselerin malları haczedilerek açık artırmayla satılmaya başlanmıştır. Fakat bu konuda Milli Korunma Kanunu engel olarak ortaya çıkmıştır. ilgili kanuna göre, eşyaların belirlenmiş olan piyasa fiyatlarının dışında satılması yasaklanmıştır. Fakat haczedilip satılan ürünler, açık artırma dolayısıyla piyasa fiyatlarının üstünde alııı bulabilmiştir. Bu durum satışlara engel teşkil edince, Milli Korunma Kanunu'na uyulmaması kararı alınarak satışlar kanun dışı bırakıımıştır. Hacizli malları satın alan kimselere de satış bedelini gösteren vesikalar, kanuna aykııılık taşıyacağı için verilmemiştir. Alııılar da bu riski göze alarak alımlar yapmışlardır (Ökte, 1951, 168).

Haciz işlemleri ve satışlar basın aracılığıyla halka duyurulmuştur. 25 Şubat 1943 tarihli gazete haberine göre; İstanbul'da vergisini vermemekte ısrar edenlerin ev ve dükkânlarının haczine devam edilmiştir. Bir gün önce 48 ev ve 29 ticarethane haczedilmiştir. Daha önce haczedilen 23 ev ve 12 ticarethanede ise tespitler yapılmıştır. Yapılan satışlarla birlikte İstanbul'daki toplam tahsilat 123.204.716 liraya yükselmiştir (Vatan, 25 Şubat 1943, 1). Vergi tahsili süresince İstanbul'da el konulup satılan gayrimenkul adedi 885 olmuştur. Bu gayrimenkulün vergi kıymeti 2.700 .883 lira olarak belirlenmiştir. Gayrimenkullerin 330 tanesi ev, 97 tanesi dükkân, 190 tanesi arsa, 80 tanesi 
apartman, 42 tanesi depo, 7 tanesi han, 8 tanesi fabrika, geriye kalanlar ise çeşitli yapılardır. Satımadığı için hazineye tapulanan emlak ise 73 parçadır (Ökte, 1951, 164).

Vergi uygulamasının başladığı günlerde Cumhurbaşkanı İsmet İnönü, yeni verginin gerekliliği üzerinde durarak, bu girişimi desteklediğini gösteren bir konuşmayı 24 Aralık 1942 tarihinde İstanbul Halk Partisi Vilayet Kongresi'nde yapmıştır. Konuşmasında Varlık Vergisi'ne değinerek, devletin selameti için gerektiğinde fedakârlık yapılabileceğini, bu fedakârlıkların kimi zaman çiftçiyi, kimi zaman tüccarı zora sokabileceğini, vatandaşın devletin taleplerini iyi niyetle karşılamaları gerektiğini belirtmiş ve sözlerine şöyle devam etmiştir: “... Bu vatanda herkes şimdiye kadar emniyet ve huzur içinde kazanmış, yaşamıştır. Bundan sonra da daima da herkes Cumhuriyet kanunlarının himayesinde ve medeniyet içinde çalışıp kazanacaktır. Her vatandaşın devlete karşı vazifelerini iyi niyetle, sabırlı, ciddi olarak yapmalarını istemek devletin hakkıdır...(Barutçu, 2001, 603)." Başbakan Saraçoğlu da vergi konusunda basına bir değerlendirmede bulunmuş, vergi uygulamasının arkasında olduklarını açıkça ifade etmiştir. Başbakan; Türk milleti ve köylüsünün asırlar boyunca üzerine yüklenen sorumlulukları büyük fedakârlıklarla yerine getirdiğini, fakat içinde bulunulan savaş durumuna rağmen bazı kimselerin hükümetin isteklerine kulak asmadıklarını, kendilerine gösterilen misafirperverlik sayesinde zengin olmalarına rağmen üzerlerine düşen görevleri yerine getirmediklerini, bu nedenle de Varlık Vergisi'nin bu tip kimseler üzerinde en şiddetli şekilde uygulanacağını belirmiştir (Cumhuriyet, 21 Ocak 1943, 1).

Varlık Vergisi tahsilatı 1943 yılı Ocak ayında süratli bir şekilde devam ederken, bir yandan da vergisini ödeyemeyen ya da ödemeyenlerin bedeni yükümlülüğe tabi tutulması konusu üzerinde hazırlıklar başlatılmıştır. 12 Ocak 1943 tarihinde Resmi Gazete'de yayınlanan Bakanlar Kurulu kararıyla konuya açıklık getirilmiştir. Kabul edilen kararnamenin ismi “Varlık Vergisi Kanunu’nun Çalışma Mecburiyetine Dair Hükümleri İhtiva Eden 12 ve 13. Maddelerinin Tatbik Sureti Hakkında Talimatname" olarak belirlenmiştir. Bu kararnamenin genel hatları şu şekildedir: Bir ay içerisinde vergisini vermeyenlerle ilgili mahallin en büyük memurluğunca bir isim listesi hazırlanır. İsmi yazılı olanların sevk sırası şu şekildedir; hiç vergi vermeyenler, kısmen vergisini vermiş ama mal kaçırmış olanlar, menkul malını kaçırmayıp borcunu ödeme konusunda iyi niyetli olanlar, gayrimenkulden mükellef tutulmuş olanlar(Madde 1). Listede ismi olanlar, kadınlar hariç olmak üzere, zabıta marifetiyle kısım kısım celp ettirilir. Toplanacaklar içerisinden memur ve müstahdem olarak maaş ve ücretle çalışanlar, 18 yaşını doldurmamış olanlar, 55 yaşını geçmiş olanlar ve kadınlar tespit edilip bunlarla ilgili Bakanlar Kurulu'ndan karar çıkması beklenir.(Madde 2). íki gözü kör, kolsuz, bir ayağı bulunmayan, bir kolu ve bir ayağı yok denecek kadar sakat olan, seyahate dayanamayacak kadar hasta olanların sevkiyatı verilecek raporlarla ertelenir. Hasta olanlar hastanede ya da evlerinde devlet adına tedavi edilir. İyileşenler derhal vazife yerlerine sevk edilir(Madde 3). Celp edilenler için bir toplanma yeri tahsis edilir(Madde 4). 3. maddeye göre celp olunacaklar ulaştırma işlerinde çalışmak üzere Ulaştırma Bakanlı̆̆ı'nca belirlenen dağııım merkezlerine polis ve jandarma denetiminde gönderilir. Kadınlar, Bakanlar Kurulu'ndan sevklerine onay çıkarsa, belediye işlerinde çalışmak üzere İçişleri Bakanlığı'nca belirlenecek yerlere sevk edilirler(Madde 5). Askerlik vazifesinde bulunanların sevki bu görevlerinin bitimine bırakılır(Madde 6). Muaf sayılanların dışında kimsenin sevki geciktirilemez, 


\section{Sabit DOKUYAN}

sevk karşıtı dava açılamaz(Madde 7). Sevk edileceklerin iaşe masrafları kendilerine aittir. İlk tevzi merkezlerine varana kadar yetecek yiyeceklerini yanlarına almalıdırlar. İşelerini karşılayamayacak halde olanların yol boyunca yiyeceklerini zabıta karşılar(Madde 8). Dağıtım yerlerine ulaşan mükellefler ilgili büroya teslim edilir, Ulaştırma Bakanlığı'nca tespit edilen işi yapar. Hiç kimse ikamet ettiği ya da ticari faaliyete bulunduğu yerde çalıştırılamaz(Madde 12). Mükelleflerin maaşlarının yarısı kendilerine geriye kalan kısmı ise borçlarından düşülmek üzere ilgili mal sandığına gönderilir(Madde 13). Yiyecek, giyecek ve yatma ihtiyaçları mükellefler tarafından karşılanır(Madde 14). Mükellefler borçlarını bitirinceye dek çalışmak zorundadırlar(Madde 15). Çalışma mecburiyetinin ifası sırasında hastalananlar iaşe ve masrafları kendilerine ait olmak üzere yakındaki devlet ve belediye hastanelerinde tedavi edilirler(Madde 16) (RG, 12 Ocak 1943, 2-3).

Yukarıda detayları verilen kararnamenin 16. maddesi net bir ifade içermediği için sonraki süreçte detaylandırımak zorunda kalınmıştır. 24 Haziran 1943 tarihli Bakanlar Kurulu toplantısında madde yeni haliyle kabul edilmiştir ve özetle şu şekildedir: Hükümet ve belediye hastanelerinde tedavi altına alınanlardan ilerlemiş veremi olanlar, ameliyatla giderilmesi mümkün bulunmayan kötü huylu urları olanlar, kalp hastalığı olanlar, ilerlemiş böbrek iltihabı olanlar, siroz olanlar, çalışamayacak durumdaki felçliler, şiddetli psikolojik bozukluğu olanlar, yardıma muhtaç hale düşürecek bir vücut zayıflığı yahut ileri kansızlık hastalığı olanlar raporla tespit sonrasında, hastalıklarının derecesine göre, bir müddet yahut sürekli olarak zorunlu çalışma mükellefiyetinden muaf sayılabileceklerdir. Tedavi görenlerin hastalığının iyileşmesi ile ilgili olarak verilen doktor raporuna göre Sağlık Bakanlığı bir karar alacak ve bu karar İçişleri, Ulaştırma ve Maliye Bakanlıklarının son onayına kadar yürürlüğe girmeyecektir. Bu durumdaki mükellefler çalıştıkları yerdeki hastanede tutulmaya devam edeceklerdir (RG, 10 Temmuz 1943, 2).

Vergilerini tam olarak ödeyemeyen birçok mükellef olmuştur. Defterdarlıklar tarafından bu kimselerin listeleri valiliklere gönderilmiştir. İstanbul'da valilik, polis yardımıyla bu mükellefleri toplatarak, Sirkeci Tren Garı yanında bulunan ve Demirkapı olarak bilinen yerdeki ambarda sevk gününe kadar bekletmiştir (Aktar, 2012, 197). 20 Ocak 1943 tarihi, vergi ödemesi için verilen ek sürenin dolduğu ve tutuklamaların başlatıldığı gün olmuştur (Guttstadt, 2012, 158). 22 Ocak 1943 tarihli Cumhuriyet Gazetesi, Varlık Vergisi'ni ödemeyen 17 kişilik ilk kafilenin toplama kampına sevk edildiği haberini yayınlamıştır. Haciz işlemlerinin de bir gün önce başlatıldığı duyurulmuştur (Cumhuriyet, 22 Ocak 1943, 1). Toplama alanına gelenlerin sayısı zaman içerisinde artmış ve 27 Ocak günü borçlarını vermeyen 32 kişilik ilk kafilenin tren ile Aşkale'ye doğru yola çıtıkları haberi basında yer almıştır (Cumhuriyet, 28 Ocak 1943, 1). Tutukluların Aşkale'ye giderken Uludağ seyahatine çıkar gibi giyindikleri, ayaklarında golf pantolonları ve gözlerinde kar gözlükleri olduğu da halka duyurulmuştur (Son Posta, 28 Ocak 1943, 1).

Toplama merkezlerinde tutulan mükellefler parça parça sevk edilmeye devam edilmiştir. Bu kişilerin bazıları vergi borçlarının bir miktarını ödemişken bazı mükellefler hiç ödeme yapmamıştır. Sevki gerçekleşen ilk 45 kişiden birkaç tanesinin vergi miktarı ve ödediği miktarlar şu şekildedir: Hamparsun Erkman 400.000 lira verginin 5.000 lirasını ödemiş, Nesim Saban 300.000 lira verginin 
10.710 lirasını ödemiş, Samoel Varon 280.000 lira verginin 4.000 lirasını ödemiş, Yorgi Beyko 200.000 lira verginin 100 lirasını ödemiş, Garp Franko 375.000 lira verginin 1.000 lirasını ödemiş, Alfred Taranto 320.000 lira vergiden hiç ödeme yapmamış, Kostantin Kürkçüoğlu 200.000 lira vergiden 200 lira ödemiştir (Ökte, 1951, 152-153).

Bazı mükellefler toplama kampında iken borçlarını kapatarak bedeni çalışma yükümlülüğünden kurtulmuşlardır. 25 Şubat 1943 tarihli Vatan Gazetesi'nin haberine göre toplama kampına alınan Koço ve Yorgi Elostropulos ortaklar 24.000 liralık borçlarını ödeyerek serbest kalmışlardır. Yine gazetenin bildirdiğine göre Aşkale'ye gönderilecek yeni kafile için en az 150 kişi hazırlanmaktadır (Vatan, 25 Şubat 1943, 1). Varlık Vergisi uygulaması müddetince sevk için kampa alınanların sayısı 2.057 olmuştur. Bu rakamın 1.869 tanesi İstanbul'dandır. Borcunu ödemeyerek çalışma yerine gönderilenler ise 1.400 kişidir. Bu rakamın 1.229'u İstanbul'dandır. Çalışma yerinde ölen sayısı ise 21 kişidir ve hepsi de İstanbul'dan gelenlerin arasındandır (Ökte, 1951, 158). Ölümler; yaşlılık ve hastalık gibi doğal nedenlerden kaynaklanmıştır. Çalışanlara herhangi bir şekilde kötü muamele ve işkence yapılmamıştır (Çavdar, 2003, 326).

Verginin toplanmaya başlandığı 1943 yılının ilk aylarında ne kadar vergi toplandığı ile ilgili elde birkaç kaynak mevcuttur. Bu kaynaklardan ilki; İngiltere'nin Türkiye büyükelçisi başkanlığında İstanbul'da oluşturulmuş bulunan İngiliz Ticaret Odası tarafından yayınlanan aylık derginin 27 Şubat 1943 tarihli sayısında yer alan "yıllık rapor" başlığı altında elimize ulaşmıştır. Bu rapor içerisinde, net olmasa da, Şubat ayına kadar toplanan vergi miktarı verilmiştir. Rapora göre, 450 milyon lira civarında bir vergi tespit edilmiş ve bunun yaklaşık 200 milyon lirası toplanmıştır. Bu rapor sadece vergi rakamları vermekle kalmamış aynı zamanda Varlık Vergisi ve Türkiye ekonomisiyle ilgili kısa bir de değerlendirme yapmıştır. Bu değerlendirme ana hatlarıyla şu şekildedir: Türkiye'de milli müdafaa giderlerini karşılamak için Varlık Vergisi Kanunu kabul edilmiştir. Kanun sayesinde 763 milyon liraya ulaşmış olan tedavüldeki para miktarı 702 milyon liraya inmiştir(Ocak ayı itibariyle). Olağanüstü durumlar için vergi uygulaması normaldir fakat bu verginin tespiti aşamasında standart bir uygulama yoktur. Mükelleflere temyiz hakkı verilmemiş, ödenmediği taktirde mecburi iş yükümlüğü öngörülmüştür. Sermaye üzerine konulmuş olan bu vergi sadece mükellef olan tüccarların değil tüm piyasanın gidişatını bozma ihtimaline sahiptir. Bu nedenle Birleşik Krallıktan ihracat yapacak olanların bu durumu dikkate alarak ihtiyatlı davranmaları gerekmektedir (BCA, 30..10.0.0/85.560..19.).

Toplanan vergi miktarlarıyla ilgili diğer kaynak Vatan Gazetesi'dir. Gazetenin 23 Mart itibari ile İstanbul için vermiş olduğu rakamlar şu şekildedir: Belirtilen güne kadar 142.048.401 lira toplam vergi tahsil edilmiştir. Toplama kaplarında bulunan mükelleflerden borcunu ödeyenler salıverilmiştir. Erzurum posta treni ile 60 kişilik yeni bir grup ise Aşkale'ye sevk edilmiştir (Vatan, 23 Mart 1943, 1). Meclis tutanaklarında ise 30 Nisan itibariyle bir değerlendirme yapılmıştır ve detaylı olarak verilen rakamlar şu şekilde kayda geçmiştir: İstanbul'da 63.640 mükellefe 348.992.022 lira vergi tahakkuk etmiş, bu miktarın 165.343.133 lirası tahsil edilmiştir. İzmir'de 5.183 mükellefe 27.992 .415 lira vergi tarh edilmiş, mükellefler belirlenen miktarın 19.351.088 lirasını ödemişlerdir. Ankara'da 3.185 mükellefe 16.980 .683 lira vergi tahakkuk ettirilmiş, mükellefler 15.111.989 lira ödemişlerdir. Bur- 


\section{Sabit DOKUYAN}

sa'da 3.106 mükellef, kendilerine tahakkuk ettirilen 11.239 .940 liranın 5.405 .952 lirasını ödemiştir. Adana'da 1.674 mükellefe 9.931.37 lira vergi borcu çıkarılmıştır ve bu miktarın 7.027.471 lirası ödenmiştir. Mersin'de 823 mükellef borçlandıkları 6.193.065 liranın 5.235.844 lirasını ödemişlerdir. Diğer illerde tahsilât oranları \% 77'yi geçerken, İstanbul'daki oran \% 47 civarında kalmıştır (TBMMZC, 24 Mayıs 1943, ekler 2/282).

Toplama kamplarına gönderilen mükelleflerin durumları Varlık Vergisi'nin çok tartışılan uygulamalarının başında gelmiştir. Bu uygulama ile ilgili olarak, yukarda bahsedildiği üzere, toplama alanında bekletilen şahısların kafileler halinde sevk edildikleri bilgisi mevcuttur. Sevkiyata tabi tutulacak mükelleflerin 55 yaş üstü ve kadın olmamaları konusunda bir sınırlama var iken, bu uygulama 20 Ocak 1943 tarihli Bakanlar Kurulu'nda kabul edilen bir kararla değiştirilmiştir. Böylece çalışma yükümlülüğü bulunan ve 55 yaşın üzerindeki kişilerin de çalıştııımasının yolu açılmıştır (BCA, 30..18.1.2/101.10..19.). Maliye Bakanlığı'nın teklifi ve Bakanlar Kurulu'nun kararıyla kabul edilen bu yeni uygulama bir müddet gecikmeli olarak ancak 23 Şubat 1943 tarihli Resmi Gazete'de yayınlanarak yürürlüğe girmiştir (RG, 23 Şubat 1943, 3). Aşkale'ye gönderilecek olan kişilerin belirlenmesinde ise ülke genelinde bir standart yakalanamamıştır. Öyle ki, Adana'da belirlenen verginin \%80'i alınmasına rağmen kimse kampa gönderilmemişken, İzmir'de tahsilât oranı \%90’a ulaştığı halde buradan 93 kişi çalışma kamplarına gönderilmiştir. Fakat bu gönderilme işi aylarca geciktirilmiş ve iyi niyet sergilenmiştir. İstanbul'da ise işler sıkı tutulmuştur ve sevkiyatlar derhal başlatılmıştır (Coşar, 2004, 117).

Aşkale'ye gönderilenlerin halkın huzuru adına şehir merkezinden uzak bir yerde kamplara alınması planlanmışken, kimi zaman bu uygulamada aksaklıklar yaşanmıştır. Aşkale'de halk ile mükellefler arasında zaman zaman sıkıntılar cereyan etmiştir. Bu konuyla ilgili olarak İçişleri Bakanı Hilmi Uran tarafından 2 Temmuz 1943 tarihinde Başbakanlığa gönderilmiş olan bir yazıda, yaşanan sıkıntı genel hatlarıyla şu şekilde izah edilmiştir; 560 Varlık Vergisi mükellefi Erzurum merkezde iki okula yerleştirilmişlerdir. Bunlar çalıştırılmadan atıl vaziyette bekletilmektedirler. İaşelerini temin için dışarı çıkanlardan bazıları kadınlara sarkıntılık etmişlerdir ve bu kimselerin kontrol altında tutulması oldukça zor hale gelmiş̧ir. Bu nedenle de 70 tanesi acil olmak üzere 150 adet çadıra ihtiyaç duyulmaktadır. Varlık Vergisi mükelleflerinin şehir içinde tutulmayarak şehir dışında çalıştırılmaları gerekmektedir. Bu kimselerin şehir içinde tutulmaları hem asayiş hem de askeri garnizonun bulunması nedeniyle emniyet açısından mahzurludur. Polis güçleri bu şahısları kontrol etmekte zorlanmaktadırlar. Bu sebeplerden dolayı en kısa zamanda gereken çadırlar gönderilmeli ve mükellefler şehir dışlındaki çalışma kamplarına yollanmalıdırlar (BCA, 30..10.0.0/89.590..12.).

Varlık Vergisi'nin hararetinin sönmeye başladığı 1943 yılı sonlarına doğru bedeni mükellefiyetler konusunda da yumuşamaya gidilmiştir. Başbakanlık tarafından 3 Aralık 1943 tarihinde İçişleri, Maliye ve Ulaştırma Bakanlıklarına gönderilen bir yazı ile vergi kapsamında mükellef olan ve belirlenen vergisini ödeyemediği için çalışmak zorunda kalan vatandaşların bundan sonraki süreçte aile ve iş muhitlerinde çalışarak borçlarını ödemelerine izin çıkmıştır. Bu kararla; ilgili vatandaşlara yeni çalışma mekânlarında huzur içinde vazifelerini yerine getirme imkânı verilerek, iyi niyetli kişilere 
kolaylık tanınmıştır. Sağlanan kolaylıklara rağmen borçlarını ödemeye yanaşmayanlar için ise gerekli kanun maddeleri uygulanmaya devam edilmiştir (BCA, 30..10.0.0/135.971..24.).

Çalışma yükümlülüğünden kurutularak İstanbul’a dönenler ve kampta kalmaya devam edenlerin en büyük destekçisi ve sözcüsü İstanbul'da yayınlanan Rumca Metapolitefsis Gazetesi olmuştur. Gazete, sürekli olarak Varlık Vergisi aleyhinde yayınlar yapmış, vergi karşıtlarının yayın organı haline gelmiştir. Illk etapta; tarh edilen vergilerin yanlış olduğunu ve azınlık okullarındaki Türk öğretmenlerin öğrencilere kötü muameleler yaptığını yazan gazete, mükelleflerin zorunlu çalışma yükümlülüklerinden dönmeye başlamaları ile birlikte, bu kişilerin nazarında itibar kazanabilmek için, "sizin için divan-ı harplere verildim" şeklinde ifadeler kullanmıştır. Son olarak ise mükellefler için genel bir af ilan edilmesini ve bu kimselere ait eşya ve gayrimenkul satışlarının derhal durdurulmasını talep etmiştir (BCA, 30..10.0.0/86.569..8.).

Vergi toplama işleri ve yükümlülerin sevkleri devam ederken, verginin çıkarılmasının müsebbibi olan Başbakan Saraçoğlu çeşitli ortamlarda Varlık Vergisi'nin haklılığını dile getirmiştir. İlk olarak 17 Mart 1943 tarihinde hükümet programıyla ilgili olarak meclise yapmış olduğu bilgilendirme konuşmasında konuya değinmiş; vergi sayesinde maliyenin rahata kavuştuğunu, hesapsız ve zararlı olarak piyasada bulunan paranın çekildiğini, Merkez Bankası'nın 35 ton daha altın aldığını, son birkaç ay içerisinde de 12 milyon İngiliz lirasının banka tarafından biriktirildiğini, tüm bu gelişmeler ışı̆̆ında Türk parasın sağlam temellere oturtulduğunu belirtmiştir (TBMMZC, 17 Mart 1943, 24; RG, 18 Mart 1943,2). Başbakandan sonra söz alan Konya milletvekili Osman Şevki Uludağ da verginin ülke genelinde ve özellikle de İstanbul'da toplanmasında yaşanan sıkıntılardan bahsetmiştir. Bir memleket meselesi olmasına rağmen vergisini vermeyenlerin çok olduğunu ifade etmiş ve bu kimselerden ya verginin tahsil edilmesini yahut bu mükelleflere gereken kanuni baskının yapılmasını istemiştir. Vergi vermeyenlerin Aşkale'ye gönderilmesinde daha seri davranılması isteğini de dile getirmiştir (TBMMZC, 17 Mart 1943, 28).

Saraçoğlu'nun CHP 6. Büyük Kongresi'nin kapanış günü yaptığı ve 16 Haziran günlü gazetelere yansıyan konuşmasında da Varlık Vergisi'ne değinilmiştir. Verginin, vatan evlatları tarafından seve seve verildiğini, fakat bazı kimselerin bu verginin azınlıkları ezmek için konulduğu yönünde iddialar ortaya attığını belirterek; esasen böyle olmadığını, elde edilen 270 milyon liranın sadece 105 milyon lirasının azınlıklardan ve yabancılardan alındığını, bu kimselerin hâlâ gayrimenkullerini ve kazanç kaynaklarını elde tutmaya devam ettiklerini söyleyerek sözlerine şöyle devam etmiştir: “...Bu Varlık Vergisi ile birlikte diğer bir nevi vergi tatbik edildi ki bu vergi devlete 600 bin tona yakın hububatla bir miktar pirinç, yağ vesaire temin eylemiştir. Bu malların serbest piyasadaki fiyatlarla tutarı 600 milyon lira ediyor. Bu 600 milyona mukabil devlet yalnı 120 milyon lira verdi. Demek bu yoldan biz 480 milyon lira bir vergi tahsil etmiş olduk. Bu verginin cesim yekûnu arasında ne bir yabancının ne de bir azınlığın bir santimi bile mevcut değildir. Bundan maada, önümüzdeki yıl için bu usulü bütün toprak mahsulüne teşmil ediyoruz (4 Haziran 1943 tarihinde kabul edilmiş bulunan Toprak Mahsulleri Vergisi'nden bahsediyor) ve bu teşmilden 500 milyonla bir milyar arasında bir menfaat bekliyoruz. Bu geniş rakamda da ne yabancıların ne de azınlıkların bir santimi bulunmayacaktır... Şayet bir gün hayatın zorlukları bizi diğer vatandaşlar arasında azlıklara da müracaat zarure- 
tiyle karşı karşıya bırakacak olursa biz bu zarureti yerine getirmek için bir dakika bile tereddüt etmeyeceğiz (RG, 16 Haziran 1943, 2; Vatan, 16 Haziran 1943, 1)."

Cumhurbaşkanı İnönü ise 1 Kasım 1943 tarihinde meclisin yeni yasama yılı açılışında vergi konusunu değerlendirmiş ve Başbakanının açıklamalarını destekler bir tavır sergilemiştir. İnönü’nün konuşmasında geçen ve önem arz eden bölümler şu şekildedir: “...Vatandaşları en çok kızdıran şey, ticarette insafsızların fiyat murakabesine karşı meydan okumalarıdır. Hükümet, bu gibilerle yorulmaz bir surette uğraşmakta devam edecektir. Amansız tedbirler gerekli olursa bunda da tereddüt etmeyecektir. Bu gibi hallerin vatandaki zararları maddi olduğundan ziyade ruhi ve manevidir. Onun için ehemmiyetleri ve tesirleri de daha geniştirler... Memleket müdafaasının taşkın ihtiyaçlarını temin etmeye çalışırken altüst olmuş iktisadi şartların tesirlerini karşılamak hazine için zor oldu. Memleket ve milletin ilerlemesine esas olan masrafları göze almak sebebi ise, maliyemizi gerçekten büyük sayılacak vazifeler karşısında bırakıyor. Milletimiz, bu vaziyeti iftihar edeceğimiz bir anlayışla kavramıştır. Büyük meclisimizin istediği yeni vergileri, milletimiz yürekten ödemeye çalışıyor. Büyük davalar içinden selametle çıkmanın bedeli, kan fedakârlığı kadar da vergi tahammülüdür. Öz selameti için kanıyla ve vergisiyle sıkıntıyı göze alamayan milletler, düşman boyunduruğu altında daha çok kan ve daha çok mal kaybını yüklenmeye mecbur olmuşlardır. İkinci Cihan Harbi esnasında, hazine ihtiyaçlarını kendi kaynaklarından ve bu intizam içinde kapayabilmesi, Türk Milleti'nin daima övüneceği bir başarı olarak anılacaktır... (İnönü, 1946, 374-375)."

\section{Verginin Tasfiye Edilmesi}

Varlık Vergisi uygulaması 1943 yılı sonbaharına doğru hız kaybetmeye başlamıştır. Vergi tahsilinde çeşitli yumuşamalar gerçekleşmiştir. Illk olarak 17 Eylül 1943 tarihli meclis oturumunda, Varlık Vergisi Kanunu'na ek kanun layihası kabul edilmiştir. Kabul edilen ek kanun maddesi ile vergi mükellefi olarak belirlenen kişilerden vergilerini ödeyemeyecekleri anlaşılan hizmet erbabı ile gündelik gayrisafi kazançları üzerinden(seyyar satıcılar gibi) kazanç vergisine tabi tutulanların tahsil edilmemiş borçlarının terkine Maliye Bakanlığı selahiyetlendirilmiştir (TBMMZC, 17 Eylül 1943, 46; RG, 21 Eylül 1943, 1; Bali, 474-475). Diğer bir yumuşama ise yukarıda belirtildiği üzere 3 Aralık 1943 tarihinde, çalışma mükelleflerinin kendi muhitlerinde çalışmalarına izin veren uygulamanın yürürlüğe girmesiyle gerçekleşmiştir.

Verginin bir bütün olarak yürürlükten kaldırıması ise ancak 1944 yılında gerçekleşmiştir. Bu amaçla, vergiden kalan ve tahsil edilmeyen miktarın tasfiyesi görüşmeleri 15 Mart 1944 tarihinde mecliste gerçekleşmiştir. Konuyla ilgili Maliye Bakanı Fuat Agralı söz almıştır ve özetle şu ifadeleri kullanmıştır: Vergi süresince 316 milyonu geçen bir tahsilât yapılmıştır. Özenle takip edilen tahsilât süreci sona ermiştir. Yurt vazifesinden kaçan bazı mükelleflere yönelik müeyyideler uygulanmak zorunda kalınmıştır. Bu kesim azınlıktadır ve vatandaşlar büyük bir vatanseverlikle üzerlerine düşen vazifeyi yerine getirmişlerdir. Tahsil edilemeyen bakayanın bir kısmının artık tahsil imkânı kalmamıştır, bir kısmının ise tahsil edildiği takdirde mükellefini yokluğa sürükleyeceği kanaatine varılmıstır. Bu nedenlerle kalan borçların silinmesi için bir kanun layihası hazırlanmıştır. Eskişehir Milletvekili 
Emin Sazak da söz alarak vergisini verenlere minnetlerini sunmuştur ve bir şekilde vergi kaçıran veyahut vermeyenlerin ise affedilmesinin onları mükâfatlandırmak olacağını, bu kişilerin halk nazarında ise asla affedilmeyeceğini belirtmiştir (TBMMZC, 15 Mart 1944, 44-45). Görüşmelerin ardından "Varlık Vergisi Bakayasının Terkinine Dair Kanun"un maddelerine geçilmiştir. 4 maddeden oluşan kanuna göre; 4305 sayılı Varlık Vergisi Kanunu'na dayanılarak tespit edilmiş vergilerin verilmeyen kısmı silinmiş̧ir. Konuyla ilgili olarak mükellefler tarafından gerçekleştirilecek geçmişe dönük herhangi bir müracaatın ise artık kabul edilmeyeceği belirtilmiştir (TBMMZC, 15 Mart 1944, 45; RG, 17 Mart 1944, 1).

Verginin tasfiyesi ardından genel bir değerlendirme yapan Cumhurbaşkanı İsmet İnönü, 1 Kasım 1944 tarihli meclis yasama yılı açıışı konuşmasında şu ifadeleri kullanmıştır: “...Bütçe masrafları milletin vergileriyle ve iç istikraz ile karşılanmaya çalışılmıştır. Türk milletinin İkinci Dünya Harbi'nde devlet maliyesi için gösterdiği kabiliyet, felaketlerden korunmasının ve millet hayatını emniyet ve ilerleme yolunda yürütmenin başlıca temeli olmuştur. Ne kadar ehemmiyetli ve vergiler ve ödevler konulduğunu biliyoruz. Ancak büyük milletimizin vatanseverliği ve vergi ödemenin müstakil millet olarak yaşama şartlarından birisi olduğunu bilmesi sayesinde bugünün sert vazifelerini karşılayabiliyoruz... Ödevini iyi yürekle yerine getiren vatandaşa kolaylık gösterici ve vergi borcunu tam ödemekten kurtulmak isteyenlere tesirli olarak karşı koyucu usuller durmadan aranacak ve düzeltilecektir... (İnönü, 1946, 387)."

Varlık Vergisi kapsamında mükellef sayısı, tarh edilen vergi miktarı, silinen ve toplanan vergi miktarları ile ilgili elimizde iki farklı veri bulunmaktadır. Bunlardan birincisi 15 Mart 1944 tarihli Meclis tutanağıdır. Bu kaynağa göre Varlık Vergisi kapsamında; 114.368 mükellefe 465.384 .820 lira vergi tarh edilmiştir. Yanlış ve mükerrer yazıldığı için veyahut çeşitli nedenlerle silinen miktar 40.478.399 lira olmuştur. Böylece geriye tarh edilen miktar olarak 424.906.421 lira kalmıştır. Bu miktardan 1944 yılı Şubat ayı sonuna kadar 314.920.940 lira tahsil edilmiştir. Toplamda verginin \% 74.11'i tahsil edilmiş, 109.985.481 lirası tahsil edilememiştir. Bu miktar, kanuni olarak gereken girişimler yapıldığı halde alınma imkânı olmayan miktar olarak kabul edilmiştir (TBMMZC, 15 Mart 1944, ekler 1/1). Rakamlarla ilgili ikinci veri 13 Kasım 1950 tarihli meclis oturumunda Maliye Bakanı Halil Ayan tarafından meclise sunulmuştur ve şu şekildedir: Varlık Vergisi dahilinde 463.045.468 lira vergi tahakkuk ettirilmiştir. Bu miktarın 317.509.114 lirası tahsil edilmiştir. Kalan 145.536.354 liranın 12.313.418 lirası 17 Eylül 1943'te kabul edilip 21 Eylül günü yürürlüğe giren kanuna bağlı olarak, 34.280.782 lirası ise mükerrerlik dolayısıyla terkin edilmiştir. 98.942.153 lira ise "Varlık Vergisi Bakayasının Terkinine Dair Kanun”la silinmiştir. Bunların dışında, çoğunluğu çiftçi olan 179 mükelleften 285.598 lira olarak tahsil edilen miktar ise geri iade edilmiştir (TBMMTD, 13 Kasım 1950, 80$83)^{1}$.

\footnotetext{
11944 yılına ait olan rakamlar; daha vergi ile ilgili belgeler tam olarak tasnif edilmediğinden ve verginin kaldırılmasından önce hazırlandığı için hatalar içeriyor olabilir. 1950 yılına ait göstergeler ise; vergi kaldıııldıktan yıllar sonra verildiği ve vergi tahsilatının tüm detayları hitama erdiği için daha kesin rakamları içermektedir düşüncesi tarafımızca daha ağır basmaktadır.
} 


\section{Sabit DOKUYAN}

Varlık Vergisi'yle elde edilen gelirler genel olarak ekonomiyi düze çıkarmamıştır, karaborsacılığı engellememiştir ama o dönem için maliyeyi rahatlatmıştır. Silah altındaki askerin giderleri başta olmak üzere birçok ödeme gerçekleştirilmiştir ve bütçe açı̆̆ı belli oranlarda dengede tutulmuştur (Kayra, 2011, 207). Uygulamanın dönem ekonomik göstergelerindeki yansımaları şu şekilde gerçekleşmiş̧ir: Devletin 1942 yılındaki toplam gelir miktarı 721.366 lira, 1943 yılında ise toplam gelir miktarı 990.749 lira olmuştur (Başbakanlık İstatistik Genel Müdürlüğü, 1950, 243). Böylece iki ylın toplam devlet geliri 1.712.115 lira olarak gerçekleşmiştir. Varlık Vergisi'nden ilgili yıllarda elde edilen toplam miktar 317.509.114 lira olarak kabul edilecek olursa, iki yıllık gelir içerisindeki Varlık Vergisi oranı yaklaşık \%18,5 olarak ortaya çıkmıştır.

Diğer yandan, verginin çıkarılması konusunda önemli gerekçeler arasında gösterilen, piyasadaki para fazlalığına verginin etkisi ise şu şekilde gerçekleşmiştir; 1939 yılında piyasada dolaşan Türk lirası 307.7 milyonken bu miktar; 1940 yılında 433.6 milyon (Parasız, 1998, 62), 1941 yılında 543.5 milyon, 1942 yılında 765.5 milyon, 1943 yılında 833.6 milyon ve 1944 yılında 994.5 milyon liraya yükselmiştir (Başbakanlık İstatistik Genel Müdürlüğü, 1950, 230). Rakamlardan anlaşlacağı üzere; 1941 ile 1942 yılları arasındaki yüksek artış 1943 yılında bir miktar frenlenmiştir. Eğer artış hızında yavaşlama olmasaydı, bir önceki artış yılı oranlarından yola çıkarak, piyasada dolaşan para miktarı 1943 yılında bir milyon lirayı aşan rakamlara ulaşabilecekti. Yani Varlık Vergisi piyasadaki fazla parayı çekerek olumlu bir ekonomik tablo çizilmesine katkı sağlamıştır.

\section{Varlık Vergisi ile ilgili Tartışmalar ve Sonuç Yerine}

Varlık Vergisi hem uygulandığı dönemde hem de sonraki süreçte devamlı olarak gündeme getirilen ve sıkça eleştirilen bir konu olmuştur. Vergi ile ilgili yapılan eleştirilerin bir bölümü haklıyken, bir kısmı ise dönemin şartları dikkate alınmadan yapılan taraflı yorum olmaktan öteye geçememiştir. Vergi çok ağır bir vergi uygulamasıdır. Fakat savaş şartlarını unutmamak gerekmektedir. Vergi ile ilgili öne çıkan ve tartışılan başlıklardan birkaçı şöyledir: Vergi sadece azınlıklardan alınmıştır ve vergilendirmede adaletsiz dağılım sergilenmiştir, uygulama ile ülkedeki azınlıkların ellerindeki mallara el konularak bu kimselerin yurt dışına çıkmaları amaçlanmıştır, bedeni yükümlülük sırasında çok acımasız uygulamalar gerçekleşmiştir, savaşın yükü sadece azınlıklara ve yabancılara yüklenerek Türk halkı korunmuştur, vergi keyfí bir uygulamanın sonucudur ve bu uygulama sadece Türkiye'de cereyan etmiştir.

Varlık Vergisi, Cumhuriyet Halk Partisi'nin iktidarda kaldığı süreçte çok ciddi tartışılmamışken, Demokrat Parti'nin 1950 yılında iktidara gelmesiyle sıkça gündeme gelmiştir. Özellikle, verginin toplanması sırasında İstanbul'da defterdar olarak görev yapan Faik Ökte'nin 1951 yılında yayınladığı ve "Varlık Vergisi Faciası" başlıklı kitap büyük tartışmalara neden olmuştur. Ökte bu eserinde, vergi uygulamasını ciddi manada eleştirmiştir. Bu eleştiriler karşısında dönemin Adalar Gençlik 
Kulübü Başkanı Ahmet Arif Meriç tarafından 27 Haziran 1951 tarihinde "Varlık Vergisinin Satılmış Kahramanı Faik Ökte'ye Açık Mektup" başlıklı bir broşür hazırlanmıştır. Bu metin içerisinde Varlık Vergisi savunulmuş ve Ökte'nin eseri şiddetle eleştirilmiştir. Meriç'e göre; vergi toplanmıştır ama Romanya, Bulgaristan, Yunanistan ve Macaristan işgal altında iken Türkiye işgal karşısında daha güçlü durabilmiştir. Bu süreçte toplanan vergide adaletsizlikler yaşanmışsa da bu durum, işgalin engellenmiş olması karşısında çok küçük bir fedakârlıktan başka bir şey olmamıştır. Medeniyetin ve gücün temsilcisi olarak gösterilen İngilizler bile savaş sırasında yüksek vergiler tahsil etmişler, bunun yanı sıra mülklere dahi el koymuşlardır. Bu devletlerde, Türkiye'de olduğu gibi bir serzeniş hiç duyulmamıştır. Türkiye'de vergi ile ezildiği iddia edilenler hâlâ memleketin en zengin ve en lüks yaşayanları durumundadırlar. Sıkıntıyı yine Anadolu insanı yaşamıştır. Ökte, milli yapıya ihanet etmiş ve bunu da kendi maddi çıkarlarını gerçekleştirmek adına yapmıştır (Meriç, 1951, 1-8). Ökte'nin eseri daha sonraki süreçte, Varlık Vergisi ile ilgili olarak Türkiye ve dünyada yazılmış olan birçok esere kaynak teşkil etmiştir. Verginin eleştirilmesinden çok, ülkenin imajının zedelenmesinde bu eser önemli bir dayanak olarak kullanılmıştır.

Demokrat Parti iktidarı döneminde diğer bir tartışma ortamı ise meclis olmuştur. Seyhan Milletvekili Sinan Tekelioğlu, DP iktidarının maliye bakanı Halil Ayan'a; Varlık Vergisi konusunda yolsuzluklar yapıldığı, vergisini \%70 ödeyenler kamplara gönderilirken hiç ödemeyenlerin gönderilmediği, bazı kimseler için belirlenen vergilerin daha sonra azaltıldığı veyahut kaldırıldığı yönündeki iddiaları sözlü soru olarak yöneltmiştir. Bakan bu sorulara 3 Temmuz 1950 tarihli oturumda cevap vermiştir. Ayan; Varlık Vergisi'nin kesin rakamlar içermeyen, komisyonların arzu ve taktirlerine bırakılan, çeşitli ihbarlar yoluyla miktarları tayin edilen bir vergi olması dolayısıyla düzensizliklere sahip olduğunu belirtmiş, bu şekilde bir vergilendirmenin devlet maliyeciliği anlayışına ters düştüğünü, uygulamalarda büyük sıkıntılar yaşanmasının da kaçınılmaz olduğunu eklemiştir. Soru sahibi Tekelioğlu kürsüye gelerek, bakanın açıklamalarından tatmin olmadığını ifade etmiştir. Belirlenen vergi düzeninin suiistimallere açık olacağı başından beldir. O kadar abartılı vergiler konulmuştur ki tahammül sınırlarını aşmıştır. Maliye Bakanlığı bünyesinde kurulmuş olan ve vergilerin indirilmesi yahut tamamen kaldırımasıyla ilgilenen bir komisyonda büyük yolsuzluklar dönmüştür. Varlık Vergisi Kanunu'na göre vergilere itiraz yolu kapalıyken ve kanun dışında vergi değişikliğine gidilemezken bu komisyon kanuna muhalif hareket etmiştir. Maliye Bakanlığı aracılığıyla 50 milyon lira civarında vergi terkin edilmiştir. Sırf Adana'da 55 kişinin vergisinde iptale ya da azaltmaya gidilmiştir. İzmir'de 4 büyük şirketin 6 milyonluk vergisi silinmiştir. Bu işlem hangi yetkiyle ve kimlerce gerçekleşmiştir? Tekelioğlu'ndan sonra Maliye Bakanı tekrar söz almış, konuyla ilgili net bilgisi olmadığını ve başka bir celsede bunu detaylı olarak aydınlatmaya çalışacağını belirtmiştir (TBMMTD, 3 Temmuz 1950, 335-337).

Tekelioğlu konuyu 12 Temmuz 1950 tarihli oturumda yeniden gündeme getirmiş ve Bakan’a özetle şu soruları yöneltmiştir: Ne kadar vergi tahakkuk ettirilip bu verginin ne kadarı tahsil edilmiştir? Vergide terkin veya tadil miktarı ne kadardır ve kimlere yönelik yapılmışıır? Bu usulsüz işlemleri gerçekleştiren komisyonu kim kurmuş ve komisyon kimlerden oluşmuştur? Halen mahkemelere başvurarak haksız yere mallarının satıldığını iddia edenler vardır. Bununla ilgili bakanlığın bir çalış- 


\section{Sabit DOKUYAN}

ması var mıdır? Tekelioğlu'nun sorularına cevap vermek için zaman isteyen Ayan, arşivlerin incelenmesi gerektiğini söylemiştir. Tekelioğlu ise mahkemeler aracılığıyla birçok gözü açığın devletten büyük miktarlarda tazminatlar kazandığını ve kısa sürede bakanlık olaya el koymaz ise devletin büyük zarar edeceğini belirtmiştir. Buna örnek olarak ise vergi sırasında 7.000 lira değer biçilen ve el konulan bir bina için mahkemeden 700.000 lira değer hükmü belirlenmesini göstermiştir (TBMMTD, 12 Temmuz 1950, 568-569).

Maliye Bakanı Ayan, 13 Kasım 1950 tarihli meclis oturumunda Teklioğlu'nun sorularına cevap vermiştir ve ana hatlarıyla şu şekildedir: Vergi dahilinde 463.045 .468 lira vergi tahakkuk ettirilmiştir ve bu miktarın 317.509.114 lirası toplanmıştır. Kalan kısmın 12.313 .418 lirası 4501 sayılı kanuna bağlı olarak, 34.280 .782 lirası ise mükerrerlik dolayısıyla silinmiştir. 98.942 .153 lira ise verginin kaldırılmasıyla silinmiş̧ir. Borçlu mükelleflerin gayrimenkulleri tahsilât için haczedilmiş ve satılmıştır. Bu satılan mallardan sadece biri ile ilgili prosedüre uyulmadığı gerekçesiyle mal sahibi tarafından dava açıımış ve kazanılmıştır. Bunun haricinde bir dava kaybı ve hazinenin zarar ettiği doğru değildir. Tekelioğlu, Bakan'ın cevabından tatmin olmamıştır. Dönem devlet adamları içerisinde vergi indirimi ve silinmesi için girişimlerde bulunulduğunu, kimi şahısların ise maddi çıkar karşıllığında vergiyi düşürmek için aracı olduğunu belirtmiş̧ir. Örnek olarak Ankara'da garajı olan Karlo'nun vergisi, dönemin Maliye Bakanı Fuat Ağralı tarafından affedilmiştir. Ayrıca Hilmi Uran tarafından hazırlanan 55 kişilik listenin vergisi de bekletilmiş ve verginin terkinine dair kanunun çıkarılması sonrası bu kişilerin vergileri silinmiş̧ir. Maliye Bakanı tekrar söz alarak Varlık Vergisi'nin iyi bir uygulama olmadığını kabul ettiklerini, fakat sürekli bu konunun meclis gündemine taşınmasının uluslararası arenada iyi bir tesir bırakmayacağını belirtmiştir (TBMMTD, 13 Kasım 1950, 80-83).

Sinan Tekelioğlu 27 Kasım 1950 tarihinde vergi uygulamasını bir daha gündeme getirmiştir. Maliye Bakanı'na yönelttiği sorularda; Hilmi Uran'ın Adana ve güney illerinde, Şevket Adalan'ın İzmir ve civarında, mali müşavir Edip Görel ve diğer bazı zevatın İstanbul'da hazırlamış oldukları listelerde kimlerin isimlerinin olduğunu, bu kimselerin vergilerinden tadil ya da terkin yapılıp yapılmadığını, eski İstanbul defterdarı Faik Ökte'nin bir vergiyi iki kişi arasında neye göre paylaştırdığını, bu şahsın vergi mükelleflerinden ev alıp almadığını ve bu evin esas değeri ile aldığı değer arasında ne kadar fark olduğunu öğrenmek istemiştir. Maliye Bakanı Halil Ayan özetle şu cevabı vermiştir: Hilmi Uran iddia edildiği gibi bazı kimselere ait vergileri bir müddet durdurmuş ve verginin kaldırımasıyla da bu vergiler aftan yararlanmıştır. Bahsi geçen mevzu ile ilgili olarak Uran; Hatay, İçel ve Seyhan vilayetlerine ait bir cetveli Maliye Bakanlığı'na sunmuştur. Cetvelde 411 mükellefe 4.384.965 lira vergi tarh edilmiştir. Bu kişilerin güçlerine göre verebileceği vergi miktarı olarak ise 1.476.650 lira uygun görülmüştür. Bakan, Faik Ökte'nin aldığı evle ilgili malumatı ise 18 Aralık günü cevaplamak üzere ertelemiştir. Tekelioğlu söz alarak; Varlık Vergisi'nin hiçbir şekilde değiştirilemeyeceği bilindiği halde neye göre bu değişikliklerin yapıldığını merak ettiğini belirtmiştir. Bu yapılanların hesabının millet adına bu meclis tarafından sorulması gerektiğini dile getirmiştir. Hilmi Uran'ın haksız olarak bazı mükelleflerin vergilerini, bir ayda ödemeleri gerekirken 2 yıl bekleterek af kanununa tabi tuttuğunu tekrarlamıştır. Tekelioğlu'ndan sonra Başbakan Adnan Menderes söz almıştır 
ve özetle şu ifadeleri kullanmıştır: Uran vergi tarhlarında hatalar gördüğü için bu vergi indirimlerini yapış olabilir. Fakat ülkenin birçok yerinde hatalı vergi tarhları mevcutken bu şahıs sadece seçim bölgesindeki düzletmeleri yaparak kendi seçmenlerine bir nevi nimet dağıtmıştır. Bahsi geçen liste Bakanlar Kurulundan geçerek değişikliğe uğramamış, sadece Maliye Bakanlığı'na gitmiştir. Uzun süre bekletilen bu vergiler af kanunu ile yürürlükten kaldııımıştır. Memleket birçok konuda olduğu gibi Varlık Vergisi konusunda da çiftlik gibi idare edilmiştir. Hükümetin görevi bu yaşananların halkın gözü önüne serilmesidir (TBMMTD, 27 Kasım 1950, 211-214). Maliye Bakanının Tekelioğlu'na daha sonra cevap verme isteği ise, soru sahibinin iki kez mecliste bulunmaması nedeniyle düşmüştür.

DP iktidarının ilk döneminde yaşanan bu tartışmaların ötesinde, vergi ile ilgili olarak günümüze kadar uzanan diğer tartışma konularına gelinecek olursa; ilk olarak verginin çoğunlukla azınlıklardan alındığı ve hatta Müslümanların 10 katı kadar bir miktara ulaştığı iddiaları değerlendirilecektir. Savaş döneminde azınlıklar, Müslüman halka göre çok daha zengin durumdadırlar. Vergi, varlık vergisi olduğu için azınlıklardan tahsil edilen miktarın fazla olması bir doğru orantının sonucu olmuştur. Fakat miktar 10 kat değil sadece 2 kat civarında kalmıştır (Kayra, 2011, 192). Öyle ki; Verginin \%52'sini Gayrimüslimiler, \%29'unu Müslümanlar, \%19'unu yabancılar ödemiştir. Verginin en çok tahsil edildiği İstanbul'da tüccarlık, sanayicilik, doktorluk, pastanecilik, meyhanecilik gibi ekonomik alanların \%87'sini Ermeni, Rum ve Musevi şahısların ellerinde bulunduğu (Coşar, 2004, 108110) düşünülecek olursa, bu kadar yüksek gelir getiren iş kollarının sahiplerine daha fazla vergi tarh edilmesi bir realitenin yansıması olmuştur.

Savaş sırasında yürürlüğe konulan Varlık Vergisi ve borcunu ödemeyenlerin gönderildiği bedeni yükümlülük uygulamasının sadece Türkiye'de olduğu iddiaları da dikkat çekmektedir. Fakat dünyada birçok yerde, savaş ekonomisinin ve politikasının bir sonucu olarak, ağır vergiler yürürlüğe girmiştir. İkinci Dünya Savaşı sürecinde Amerika'da şirket kazançlarının \%94'ü Varlık Vergisi adıyla vergilendirilmiştir. Almanya'da da benzer bir vergi konulmuştur ve daha önceki yılların vergisinin \%150'si kadar bir vergi tahsil edilmiştir. İsviçre'de "Tek Vergi” adıyla servet vergisi alınmıştır. Fransa'da vergi oranları artııımış, Yunanistan'da geçici servet vergisi ve Macaristan'da da bir defalık servet vergisi uygulanmıştır (Kayra, 2011, 38-39). Diğer bir iddia olan çalışma kampları uygulamalarının da birçok ülkede ve çok daha ağır şekilde uygulandığı dikkat çekmektedir. Türkiye'de çalışma kamplarına gönderilen çok az sayıda azınlığa karşın, dünyanın çeşitli yerlerinde çok daha büyük sürgünler yaşanmıştır. İngiltere 1940 yılında, içlerinde 50.000 Yahudi sığınmacı da bulunan bütün İtalyan ve Alman ecnebileri sürgüne göndermiştir. Fransa 1939 yılı sonlarına doğru 43.000 Alman asıllı Fransız vatandaşını güney Fransa'ya sürmüştür. İsviçre ise kendisine sığınmak amaçlı gelen Yahudilerin sadece paralı olanlarını kabul etmiştir. Ülkede bulunan ve parası olmayan Yahudiler ise çalışma kamplarında çalıştırılarak borçlarını ödemeleri sağlanmıştır. Ayrıca sığınmacıların masraflarını karşılamak üzere Yahudilere yüklenen "Yahudi Vergisi" adlı bir vergi de tahsil edilmiştir. ABD savaşın başlamasının ardından 100.000 Japon asıllı vatandaşını yerleşme kamplarına sürmüştür (Kayra, 2011, 169-170). Türkiye Cumhuriyeti Devleti ise aynı dönemlerde savaşa girmeyerek hem 18 milyon vatandaşını, hem de çoğunluğu İstanbul'da bulunan yüz binlerce Rum, Ermeni, Yahudi 


\section{Sabit DOKUYAN}

ve ecnebiyi, bunun yanı sıra savaş sırasında Türkiye'ye sığınan Musevileri, Yunanistan'dan kaçan Yunanlıları ve diğer on binlerce yabancıyı savaşın acımasız şartlarının dışında tutmuştur (Kayra, 2011, 244-245).

Daha önce değinildiği üzere Türkiye, vergi ödemeyen azınlıklardan 1.400 tanesini çalışma mükellefiyetine tabi tutmuştur. Fakat unutulmamalıdır ki aynı dönemde, savaş şartlarının bir gerekliliği olarak ve Milli Korunma Kanunu'na dayanılarak on binlerce Türk kökenli vatandaş zorunlu çalışma mükellefiyetini yerine getirmiştir. Sadece Ereğli kömür havzasında 1942-1944 yılları arasında çalışan yıllık ortalama 25.000 kişinin yarısı zorunlu çalışma yükümlüsü olarak görev yapmıştır. Bu kişiler çok zor şartlarda ve günlük 11 saat çalışmışlardır. İşçilerden, ilgili yıllar içerisinde, çalışma esnasında ölenlerin sayısı ise 250'den fazla olmuştur (Kayra, 2011, 172-173).

Bedeni mükellefiyet uygulaması mükelleflere eziyet çektirmek amaçıı yapılmamıştır. Öyle ki, hapis cezaları bu uygulamadan daha az imkânlara sahip ve daha ağır bir uygulama olacaktı. İş mükellefiyeti konusu, vergi ödemeyenleri caydırmak ve ödemeye yönlendirmek için yapılmış bir göz korkutma eylemi olarak kalmıştır (Kayra, 2011, 162). Zaten çalışma kamplarında hayat çok da zor değildir. Aşkale'ye gidenler, kışların uzun sürmesi dolayısıyla yılın büyük kısmını evlerinde ve kahvehanelerde geçirmişlerdir. Sınırlamalara rağmen özel kanallardan para getirterek rahat bir yaşam sürmüşlerdir. O kadar ki şehir hayatı ve ticaret yüzünden sıhhatini kaybedenlerden, Aşkale'de sağlık bulanlar, evlerine gayet sıhhatli ve neşeli dönenler dahi olmuştur (Ökte, 1951, 159).

Varlık Vergisi uygulamaları dolayısıyla azınlıkların Türkiye'yi terk ettiği konusuna gelinecek olursa; öncelikli olarak Başbakanlık İstatistik Umum Müdürlüğü İstatistik Yıllığı içerisinde yer alan 1927-1960 yılları arasında Türkiye nüfusunun, konuşulan anadiller kriteriyle sınıflandırılmış etnik dağııım tablosuna bakmak aydınlatıcı olacaktır (Devlet İstatistik Enstitüsü, 1965, 77; Başbakanlık İstatistik Umum Müdürlüğü, 1959, 81):

Tablo 3. 1927-1960 yılları arasında Türkiye'nin Etnik Yapısı

\begin{tabular}{lrrrrrr}
\hline \hline Diller & \multicolumn{7}{c}{ Yıllar } \\
\hline & 1927 & 1935 & 1945 & 1950 & 1955 & 1960 \\
Türkçe & $11.778^{*}$ & 14.202 & 16.598 & 18.255 & 21.422 & 25.173 \\
Rumca & 120 & 109 & 89 & 89 & 80 & 65 \\
Ermenice & 64 & 59 & 56 & 53 & 54 & 53 \\
İbranice & 69 & 57 & 62 & 35 & 33 & 23 \\
\hline
\end{tabular}

* Rakamlar x1000 olarak verilmiştir.

Tablo incelendiğinde: Varlık Vergisi'nin esas hedefi olduğu iddia edilen Yahudi nüfusunun savaş öncesi döneme göre 1945 yılında artış gösterdiği görülmüştür. 1950 yılındaki azalma ise daha 
çok İsrail Devleti'nin 1948 yılında kurulması sonrasında bu ülkeye yapılan göçlerle ilgilidir. Rumca konuşan nüfusa bakıldığında; bu kitlenin Cumhuriyetin kuruluşundan itibaren genel itibariyle bir azalma eğiliminde olduğu fakat 1945-1950 yılları olarak verebileceğimiz savaş sonrası dönemde bu azalmanın durduğu görülmektedir. Ermeni nüfusunda ise önemli bir dalgalanma görülmemektedir. Tablodan yola çıkarak bir sonuca varılacak olursa; Varlık Vergisi ağır bir vergi olmasına rağmen, ülkedeki azınlıkların sayılarının büyük oranda düştüğü iddiaları gerçekliği yansıtmamaktadır.

Varlık Vergisi bir keyfiyet eseri olmayıp, bir zaruret vergisidir, olağanüstü hâl uygulamasıdır. Bu vergi yerine izlenebilecek diğer yol olarak dış borç alınması düşünülebilirdi. Fakat hükümet, savaş yıllarında stok ve karaborsacılıkla servet edinenlerden vergi alma yolunu seçmiştir. Çünkü bu yollarla kazanılan paralar çok büyük miktarlardadır ve çoğunlukla da vergilendirme dışı kalmıştır (Aydemir, 2011, 230-233). Şevket Süreyya Aydemir, Varlık Vergisi döneminde İstanbul milletvekili olarak mecliste bulunan Avram Galanti ile yaptığı bir görüşmede; Galanti'nin Varlık Vergisi'ni acımasız bulmasına tepki göstermiş, Osmanlı́nın azınlıkların her türlü rahatını sağladığını, buna karşılık askeri destek alamadığını ve kimi zaman da vergilerin dahi tam olarak verilmeyip büyük servetler kazanıldığını hatırlatmıştır. Türklerin savaşlarda kaybettikleri canlar için bile birkaç yüz milyon liralık vergi verilmesinin çok görülmemesi gerektiğini söyleyerek şu ifadelerle sözlerine devam etmiştir: “...İsterseniz bizim dökülen kanlarımız ve sonu gelmez askerlik emeklerimizle, sizin şu bir avuç vergi fazlanızı karşılaştıracağımıza, sizin biriken servetlerinizle, bizim biriken kan ve askerlik haklarımızı teraziye koyarak hesaplaşalım. Eğer biz haksız çıkarsak, verginiz silinsin, ne dersiniz?”. Bu ifade üzerine Galanti verginin haklılı̆ını kabul etmiş ve “...Yalnız bütün malımızı, mülkümüzü değil, cemaatlerimizin bütün fertlerinin canlarını da teraziye koyarsak, biz sizin asırlık kan ve askerlik haklarınızı ödeyemeyiz. Aldığınız vergi helal olsun...(Aydemir, 2011, 236).”

Halkın fedakârlığının en iyi örneği olan Milli Mücadele yıllarına bakıldığı zaman, ülkenin kurtuluşu için Anadolu insanının sadece canını değil, tüm maddi imkânlarını da seferber ettiği açıkça görülmektedir. Varlık Vergisi'nin çok ağır oluşunun gerçekliğinin yanı sıra, Anadolu ihtilalinin gerçekleştiği Kurutuluş Savaşı döneminde çıkarılmış bulunan Tekalif-i Milliye Emirleri'ne göz atmak yerinde olacaktır. 7-8 Ağustos 1921 tarihinde, Sakarya Meydan Muharebesi'nin hemen öncesinde yayınlanan Tekalifi Milliye Emrileri'nin içeriği kısaca şu şekildedir: Her kazada bir komisyon oluşturulacaktır. Her hane birer kat çamaşıı, bir çift çorabı ve çarığı komisyona teslim edecektir. Tüccar ve ahalinin elinde bulunan kumaş, iplik, bez, deri, çarık, çivi, nal, yular, semer gibi lazım gelen mamullerin stoklarının \%40'ına, bedeli sonra ödenmek kaydıyla el konulacaktır. Yine buğday, saman, arpa, fasulye, şeker, kasaplık hayvan, yağ, zeytin ve mum gibi ihtiyaç ürünlerinin stoklarının da \%40'ına el konulacaktır. Askeri yükler halkın elinde bulunan nakliye araçları vasıtasıyla ayda bir olmak üzere 100 km'lik mesafeye taşınacaktır. Sahibi tarafından terk edilmiş ve askerin işine yarayacak tüm mallara el konulacaktır. Savaşta kullanılabilecek ve halkın elinde mevcut bulunan silah ve cephane üç gün içerisinde teslim edilecektir. Benzin, makine yağları, araç lastikleri, tutkal, telefon, kablo, pil gibi ürünlerin stoklarına \%40 oranında el konulacaktır. Demirci, marangoz, saraç, arabacı gibi zanaatkarlar ve imalathaneleri, bu esnaf ve imalathanelerin imal kabiliyetleri, kılıcmızrak-eyer gibi araçları yapabilecek olan zanaatkarların isimleri, sayıları ve durumları tespit edile- 
cektir. Halk elinde bulunan dört tekerli yaylı araba, at-öküz arabaları, kağnılar (tüm teçhizatlarıyla birlikte olmak üzere) ve binek-taşıma hayvanlarının \%20'sine el konulacaktır. Özet olarak verdiğimiz bu emirler yayınlandıktan sonra Ankara, Kastamonu, Samsun, Konya, Eskişehir mıntıkalarında İstiklal Mahkemeleri kurularak uygulamanın yürütülmesi amaçlanmıştır (Atatürk, 1969, 615-617). Bu olağanüstü vergi uygulamasıyla Varlık Vergisi karşılaştııılığında, Tekalifi Milliye Emirleri'nin halk üzerine ne kadar ağır bir yük getirdiği açıkça ortaya çıkmaktadır. Fakat ülke savunması adına halk bu vergilerin çok daha fazlasını kendi istekleriyle vermişlerdir.

Varlık Vergisi yukarda değinilen konular çerçevesinde 1950'lerden sonra da çok fazla tartışımıştır. Fakat mesele, üzerinden zaman geçmesiyle birlikte, tamamen siyasallaşmış ve dönem iktidarına taraftarlık ya da karşıtık anlamlarıyla ön plana çıkarılmıştır. Türkiye Cumhuriyeti tarihi adına çok önemli sayılabilecek bir konu, dünyada birçok örneği olmasına ve dönem şartlarının bir gerekliliği sonucu gerçekleşmesine rağmen, çoğunlukla objektif değerlendirmeye tabi tutulmamıştır. Dönem bürokratlarının şahsi hataları yüzünden birçok haksızlıkların ve adam kayırmaların da yaşanmış olduğu bu vergiyi, ülkenin saygınlığını zedeleyecek şekilde anlatmaya çalışmak çok da bilimsel ve etik bir davranış olarak değerlendirilemez.

\section{Kaynaklar}

\section{Arşiv Belgeleri ve Resmi Yayınlar}

\section{Başbakanlık Cumhuriyet Arşivi(BCA)}

BCA, Dosya: 262, Fon Kodu: 30..18.1.2, Yer No: 90.23..1.

BCA, Dosya: 75130, Fon Kodu: 30..18.1.2, Yer No: 109.55..2.

BCA, Dosya: ?,Fon Kodu: 490..1.0.0,Yer No: 5.26..30.

BCA, Dosya: 146-1,Fon Kodu: 30..18.1.2,Yer No: 102.57..10.

BCA, Dosya: 12460,Fon Kodu: 30..10.0.0,Yer No: 135.971..23.

BCA, Dosya: 124-67,Fon Kodu: 30..18.1.2,Yer No: 100.110..17.

BCA, Dosya: 14630,Fon Kodu: 30..10.0.0,Yer No: 144.31..13.

BCA, Dosya: 85289,Fon Kodu: 30..10.0.0,Yer No: 85.560..19.

BCA, Dosya: ?,Fon Kodu: 30..18.1.2,Yer No: 101.10..19.

BCA, Dosya: 87117,Fon Kodu: 30..10.0.0,Yer No: 89.590..12.

BCA, Dosya: 12461,Fon Kodu: 30..10.0.0,Yer No: 135.971..24.

BCA, Dosya: 8668,Fon Kodu: 30..10.0.0,Yer No: 86.569..8.

\section{Türkiye Büyük Millet Meclisi Zabıt Ceridesi (TBMMZC)}


TBMMZC, 18 Ocak 1940, 6. Dönem, Cilt: 8.

TBMMZC, 18 Mart 1940, 6. Dönem, Cilt: 9.

TBMMZC, 2 Şubat 1942, 6. Dönem, Cilt: 23.

TBMMZC, 11 Kasım 1942, 6. Dönem, Cilt: 28.

TBMMZC, 17 Mart 1943, 7. Dönem, Cilt: 1.

TBMMZC, 24 Mayıs 1943, 7. Dönem, Cilt: 2.

TBMMZC, 17 Eylül 1943, 7. Dönem, Cilt: 5.

TBMMZC, 26 Ocak 1944, 7. Dönem, Cilt: 7.

TBMMZC, 15 Mart 1944, 7. Dönem, Cilt: 8.

Türkiye Büyük Millet Meclisi Tutanak Dergisi(TBMMTD)

TBMMTD, 23 Ocak 1946, 7. Dönem, Cilt: 21.

TBMMTD, 3 Temmuz 1950, 9. Dönem, Cilt: 1.

TBMMTD, 12 Temmuz 1950, 9. Dönem, Cilt: 1.

TBMMTD, 13 Kasım 1950, 9. Dönem, Cilt: 2.

TBMMTD, 27 Kasım 1950, 9. Dönem, Cilt: 2.

\section{Resmi Gazete}

Resmi Gazete, 15 Haziran 1927.

Resmi Gazete, 25 Mart 1934.

Resmi Gazete, 29 Mayıs 1935.

Resmi Gazete, 10 Temmuz 1940.

Resmi Gazete, 14 Şubat 1941.

Resmi Gazete, 21 Şubat 1941.

Resmi Gazete, 30 Ocak 1942.

Resmi Gazete, 12 Kasım 1942.

Resmi Gazete, 5 Ocak 1943.

Resmi Gazete, 12 Ocak 1943.

Resmi Gazete, 23 Şubat 1943.

Resmi Gazete, 18 Mart 1943. 
Resmi Gazete, 16 Haziran 1943.

Resmi Gazete, 10 Temmuz 1943.

Resmi Gazete, 21 Eylül 1943.

Resmi Gazete, 5 Kasım 1943.

Resmi Gazete, 17 Mart 1944.

Resmi Gazete, 1 Kasım 1944.

Yıllıklar

Başbakanlık İstatistik Genel Müdürlüğü Türkiye İstatistik Yıllığı 1950, Cilt 18, Ankara.

Başbakanlık İstatistik Umum Müdürlüğü İstatistik Yıllığı 1959, Ankara.

Devlet İstatistik Enstitüsü Türkiye İstatistik Yıllığı 1964/1965, Ankara.

\section{Süreli Yayınlar}

Cumhuriyet Gazetesi, 12 Ocak 1942.

Cumhuriyet Gazetesi, 14 Ocak 1942.

Cumhuriyet Gazetesi, 21 Ocak 1943.

Cumhuriyet Gazetesi, 22 Ocak 1943.

Cumhuriyet Gazetesi, 28 Ocak 1943.

Son Posta Gazetesi, 28 Ocak 1943.

Son Telgraf Gazetesi, 3 Haziran 1942.

Tanin Gazetesi, 9 Eylül 1946.

Ulus Gazetesi, 17 Ocak 1942.

Ulus Gazetesi, 28 Şubat 1942.

Vatan Gazetesi, 6 Aralık 1940.

Vatan Gazetesi, 4 Kasım 1942.

Vatan Gazetesi, 25 Şubat 1943.

Vatan Gazetesi, 23 Mart 1943.

Vatan Gazetesi, 16 Haziran 1943.

Vatan Gazetesi, 9 Eylül 1946.

52 


\section{Hatıralar, Telif ve Tetkik Eserler, Tezler}

Acar, Y. (1999). Tarihsel Açıdan Türkiye Ekonomisi ve İlenen Iktisadi Politikalar(1923-1963), Vipaş Yayınları, Bursa.

Ahmad, F. (2010). Demokrasi Sürecinde Türkiye(1945-1980), Hil Yayınları, İstanbul.

Akandere, O. (1998). Milli Şef Dönemi Çok Partili Hayata Geçişte Rol Oynayan liç ve Dış Tesirler(1938-1945), ìz Yayıncilık, İstanbul.

Aktar, A. (2012). Varlık Vergisi ve Türkleştirme Politikaları, İletişim Yayınları, İstanbul.

Atatürk, M.K. (1969). Nutuk, Cilt 2, Milli Eğitim Basımevi, İstanbul.

Aydemir, Ş.S. (2011). Ikinci Adam,(1938-1950), Cilt II, Remzi Kitabevi, İstanbul.

Bali, R. (1999). Cumhuriyet Yıllarında Türkiye Yahudileri Bir Türkleştirme Serüveni(1923-1945), İletişim Yayınları, İstanbul.

Barutçu, F.A. (2001). Siyasi Hatıralar, 21. Yüzyıl Yayınları, Ankara.

Coşar, N. (2004). Kriz, Savaş ve Bütçe Politikası(1926-1950), Bağlam Yayıncılık, İstanbul.

Çavdar, T. (2003). Türkiye Ekonomisinin Tarihi(1900-1960), İmge Kitabevi, Ankara.

Çınar, T. (2008). "1942: A'dan Z’ye Bozuk Devletin Yeniden Yapılanması Girişimlerinin Yükselişi ve Düşüşü", Açıklamalı Yönetim Zaman Dizini(1940-1949), (Editör: Birgül Ayman Güler), AÜSBF Kamu Yönetimi Araştırma ve Uygulama Merkezi, Ankara. (226-357).

Ekzen, N. (1980). 1946-1958-1970 Devalüasyonları, Maliye Bakanlığı Tetkik Kurulu Yayınları, Ankara.

Guttstadt, C. (2012). Türkiye, Yahudiler ve Holokost, İletişim Yayınları, İstanbul.

Güner, A.O. (1978). Türkiye'nin Kalkınması İktisadi Devlet Teşekkülleri, Damla Yayınevi, İstanbul.

Güneş, G. (2002). "Türkiye'de Savaş Ekonomisi Uygulamaları ve Toplumsal Yaşama Etkileri”, Türkler Ansiklopedisi, Cilt 17, Yeni Türkiye Yayınları, Ankara. (615-621).

Hiç, M. (2002). "Cumhuriyet Döneminde Türkiye Ekonomisi”, Türkler Ansiklopedisi, Cilt 17, Yeni Türkiye Yayınları, Ankara. (541-564).

İnönü, İ. (1946). Inönü’nün Söylev ve Demeçleri(1919-1946), Cilt 1, Milli Eğitim Basımevi, İstanbul.

İnönü, ì. (2008). Defterler(1919-1973), Cilt: 1, (Hazırlayan: Ahmet Demirel), Yapı Kredi Yayınları, İstanbul.

Karabekir, K. (2009). Günlükler(1906-1948), Cilt 2, Yapı Kredi Yayınları, İstanbul.

Karpat, K. (2008). Türk Demokrasi Tarihi, İmge Kitabevi, Ankara. 
Sabit DOKUYAN

Kayıran, M. (1995). “Türk Tarımında Modernleşme Çabaları (1923-1950)”, Hacettepe Üniversitesi Atatürk Illkeleri ve Inkılap Tarihi Enstitüsü, Ankara. (Yayınlanmamış Doktora Tezi).

Kayra, C. (2011). Savaş, Türkiye, Varlık Vergisi, Tarihçi Kitabevi, İstanbul.

Kolaç, B. (2002). “Türkiye'de Hububat Politikaları(1923-1950)", Türkler Ansiklopedisi, Cilt: 17, Yeni Türkiye Yayınları, Ankara. (660-676).

Köklü, A. (1947). Türkiye'de Para Meseleleri, Milli Eğitim Basımevi, Ankara.

Köksal, B. A. ve ilkin, A. R. (1973). Türkiye'de Iktisadi Politikanın Gelişimi(1923-1973), Yapı Kredi Bankası Yayınları, İstanbul.

Lewis, B. (1996). Modern Türkiye'nin Doğuşu, TTK Basımevi, Ankara.

Meriç, A. A. (1951). Varlık Vergisinin Satılmış Kahramanı Faik Ökte'ye Açık Mektup, Raşit Bütün Matbaası, İstanbul.

Metintaş, M. Y. ve Kayıran, M. (2008). “Refik Saydam Hükümetleri Döneminde Türkiye'nin Ekonomi Politikası (1939-1942)”, Eskişehir Osmangazi Üniversitesi Sosyal Bilimler Dergisi, Yıl 9, Sayı 2. (155-183).

Ökçün, A. G. (1968). Türkiye Iktisat Kongresi(1923-Izmir), AÜSBF Yayınları, Ankara.

Ökte, F. (1951). Varlık Vergisi Faciası, Nebioğlu Yayınevi, İstanbul.

Özkan, M. S. ve Temizer, A. (2009). “ikinci Dünya Savaşı Yıllarında Türkiye'de Karaborsacılık”, Uluslararası Sosyal Araştırmalar Dergisi, Volume 2 / 9 Fall. (319-325).

Parasız, ì. (1998). Türkiye Ekonomisi (1923'ten Günümüze Türkiye'de iktisat ve İstikrar Politikaları Uygulamaları), Ezgi Kitabevi Yayınları, Bursa.

Rozaliyev, Y. N. (1978). Türkiye'de Kapitalizmin Gelişme Özellikleri(1923-1960), Onur Yayınları, Ankara.

Serin, N. (1963). Türkiye'nin Sanayileşmesi, Sevinç Matbaası, Ankara.

Serin, N. (1975). Dış Ticaret ve Dış Ticaret Politikası(1923-1973), Ankara Üniversitesi Siyasal Bilgiler Fakültesi Yayınları, Ankara.

Sevim, F. (1978). Dünya Uygarlığı ve Türk Sosyo-Ekonomik Tarihi, İpek Yayınevi, İstanbul.

Tokgöz, E. (1991). Türkiye'nin Iktisadi Gelişme Tarihi, Hacettepe Üniversitesi İiBF Yayınları, Ankara.

Tunçay, M., Koçak, C. ve Özdemir, H. (1995). Çağdaş Türkiye(1908-1980), Cilt 4, Cem Yayınevi, İstanbul.

Ünal, O. (1994). Türkiye'de Demokrasi'nin Doğuşu, Milliyet Yayınları, İstanbul. 
Durmuş, Y., Akbıyık, Y., Özkaya, Y. vd. (2008). Türkiye Cumhuriyeti Tarihi, Cilt 2, ATAM Yayınları, Ankara.

Yetim, G. (2006). 1939-1950 Arasında Türkiye'deki Sosyo-Ekonomik Durumun Çok Partili Hayata Etkileri, İstanbul Üniversitesi Sosyal Bilimler Enstitüsü, İstanbul. (Yayınlanmamı̧̧ Yüksek Lisans Tezi). 
